Article

\title{
Insertion of Phosphenium Ions into a Bicyclo[1.1.0]Tetraphosphabutane Iron Complex
}

\author{
Martin Weber (D), Gábor Balázs, Alexander V. Virovets (D), Eugenia Peresypkina (D) and Manfred Scheer*(D) \\ Institute of Inorganic Chemistry, University of Regensburg, Universitätsstrasse 31, 93040 Regensburg, Germany; \\ Martin2.Weber@chemie.uni-regensburg.de (M.W.); gabor.balazs@chemie.uni-regensburg.de (G.B.); \\ avvirovets@yahoo.com (A.V.V.); eugeniaperesypkina@gmail.com (E.P.) \\ * Correspondence: manfred.scheer@ur.de
}

check for updates

Citation: Weber, M.; Balázs, G.;

Virovets, A.V.; Peresypkina, E.; Scheer, M. Insertion of Phosphenium Ions into a Bicyclo[1.1.0]Tetraphosphabutane Iron Complex. Molecules 2021, 26 , 3920. https://doi.org/10.3390/ molecules 26133920

Academic Editor: Erika Bálint

Received: 9 June 2021

Accepted: 23 June 2021

Published: 26 June 2021

Publisher's Note: MDPI stays neutral with regard to jurisdictional claims in published maps and institutional affiliations.

Copyright: (c) 2021 by the authors. Licensee MDPI, Basel, Switzerland. This article is an open access article distributed under the terms and conditions of the Creative Commons Attribution (CC BY) license (https:// creativecommons.org/licenses/by/ $4.0 /)$.
Abstract: By reacting $\left[\left\{\mathrm{Cp}^{\prime \prime \prime} \mathrm{Fe}(\mathrm{CO})_{2}\right\}_{2}\left(\mu, \eta^{1: 1}-\mathrm{P}_{4}\right)\right](\mathbf{1})$ with in situ generated phosphenium ions $\left[\mathrm{Ph}_{2} \mathrm{P}\right][\mathrm{A}]\left([\mathrm{A}]^{-}=[\mathrm{OTf}]^{-}=\left[\mathrm{O}_{3} \mathrm{SCF}_{3}\right]^{-},\left[\mathrm{PF}_{6}\right]^{-}\right)$, a mixture of two main products of the composition $\left[\left\{\mathrm{Cp}^{\prime \prime \prime} \mathrm{Fe}(\mathrm{CO})_{2}\right\}_{2}\left(\mu, \eta^{1: 1}-\mathrm{P}_{5}\left(\mathrm{C}_{6} \mathrm{H}_{5}\right)_{2}\right)\right]\left[\mathrm{PF}_{6}\right]$ (2a and 3a) could be identified by extensive ${ }^{31} \mathrm{P}$ NMR spectroscopic studies at $193 \mathrm{~K}$. Compound 3a was also characterized by X-ray diffraction analysis, showing the rarely observed bicyclo[2.1.0]pentaphosphapentane unit. At room temperature, the novel compound $\left[\left\{\mathrm{Cp}^{\prime \prime \prime} \mathrm{Fe}\right\}\left(\mu, \eta^{4: 1}-\mathrm{P}_{5} \mathrm{Ph}_{2}\right)\left\{\mathrm{Cp}^{\prime \prime \prime}(\mathrm{CO})_{2} \mathrm{Fe}\right\}\right]\left[\mathrm{PF}_{6}\right]$ (4) is formed by decarbonylation. Reacting 1 with in situ generated diphenyl arsenium ions gives short-lived intermediates at $193 \mathrm{~K}$ which disproportionate at room temperature into tetraphenyldiarsine and $\left[\left\{\mathrm{Cp}^{\prime \prime \prime} \mathrm{Fe}(\mathrm{CO})_{2}\right\}_{4}\left(\mu_{4}, \eta^{1: 1: 1: 1}\right.\right.$ $\left.\left.\mathrm{P}_{8}\right)\right][\mathrm{OTf}]_{2}(5)$ containing a tetracyclo[3.3.0.0 $\left.0^{2,7} \cdot 0^{3,6}\right]$ octaphosphaoctane ligand.

Keywords: bicyclo[1.1.0]tetraphosphabutane; phosphorus activation; arsenium ions; phosphenium ions; tetracyclo[3.3.0.0 2,7 $.0^{3,6}$ ]octaphosphaoctane; $\mathrm{P}_{4}$ butterfly complex; $\mathrm{R}_{2} \mathrm{P}^{+}$insertion

\section{Introduction}

The activation of small molecules such as $\mathrm{N}_{2}$ or $\mathrm{P}_{4}$ with reactive transition metal fragments or main group reactants is one of the important aspects of modern chemistry. More energy-efficient reaction pathways leading, by higher atom economy, to compounds containing nitrogen or phosphorus seem more tangible with every new insight gained into the activation pathways [1-5]. The opening of one $\mathrm{P}-\mathrm{P}$ bond of the $\mathrm{P}_{4}$ tetrahedron leading to the tetraphosphabicyclo[1.1.0] unit (also called the butterfly unit) is one of the first activation steps for $\mathrm{P}_{4}$ and is well-studied for reactive transition metal compounds. The activation leads to a cage-like compound by insertion of a metal fragment as observed for example in $\left[\mathrm{L}_{2} \mathrm{RhCl}\left(\eta^{1: 1}-\mathrm{P}_{4}\right)\right]\left(\mathrm{L}=\mathrm{PPh}_{3}, \mathrm{P}(\mathrm{m} \text {-tol })_{3}, \mathrm{P}(\mathrm{p} \text {-tol })_{3}, \mathrm{AsPh}_{3}\right)(\mathrm{I})$, the first reported polyphosphorus ligand complex (Scheme 1) [6]. Also, a $\mu, \eta^{1: 1}$-coordination mode can be observed, e.g., in the complex $\left[\left\{\mathrm{Cp}^{\prime \prime \prime} \mathrm{Fe}(\mathrm{CO})_{2}\right\}_{2}\left(\mu, \eta^{1: 1}-\mathrm{P}_{4}\right)\right]\left(\mathrm{Cp}^{\prime \prime \prime}=\mathrm{C}_{5} \mathrm{H}_{2}\left(\mathrm{C}\left(\mathrm{CH}_{3}\right)_{3}\right)_{3}\right)$ (1), synthesized by the reaction of $\left[\mathrm{Cp}^{\prime \prime \prime} \mathrm{Fe}(\mathrm{CO})_{2}\right]_{2}$ with white phosphorus $[7,8]$. Since the highest occupied molecular orbital (HOMO) in $\mathbf{1}$ is localized on the "wing tip" phosphorus atoms of the butterfly unit, we have investigated the reactivity towards Lewis-acidic transition metal fragments [9-12] or the coinage metal salts such as $\mathrm{Cu}(\mathrm{I}), \mathrm{Ag}(\mathrm{I})$ and $\mathrm{Au}(\mathrm{I})$ [11-13]. In most of the cases, the coordination of the "wing tip" phosphorus atoms of the intact butterfly to the electron-poor metal centre is observed, but also a rearrangement to a cyclo- $\mathrm{P}_{4}$ unit. The complex $\left[\left\{\mathrm{Cp}^{*} \mathrm{Cr}(\mathrm{CO})_{3}\right\}_{2}\left(\mu, \eta^{1: 1}-\mathrm{P}_{4}\right)\right]\left(\mathrm{Cp}^{*}=\mathrm{C}_{5}\left(\mathrm{CH}_{3}\right)_{5}\right)$, which is similar to 1 , isomerizes in reactions with $\mathrm{M}(\mathrm{CO})_{5}(\mathrm{M}=\mathrm{Cr}, \mathrm{Mo})$ entities, while fragmentation occurs in reactions with $\mathrm{N}$-heterocyclic carbenes $[13,14]$. Beside transition metal compounds, $\mathrm{P}_{4}$ can be activated by main group electrophiles [2,15]. A prominent example for main group electrophiles which have been used in the activation of $\mathrm{P}_{4}$ are phosphenium cations $\left[\mathrm{R}_{2} \mathrm{P}\right]^{+}$ ( $R$ = alkyl or aryl) which, in general, are too reactive to be isolated, but can be generated in situ by halogen abstraction from halogenophosphines with abstractors, such as, for instance $\mathrm{GaCl}_{3}$, silver or thallium salts in the presence of a suitable substrate to react with. 


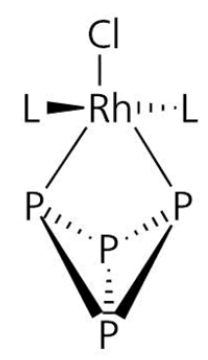

I

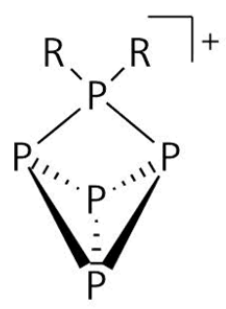

II

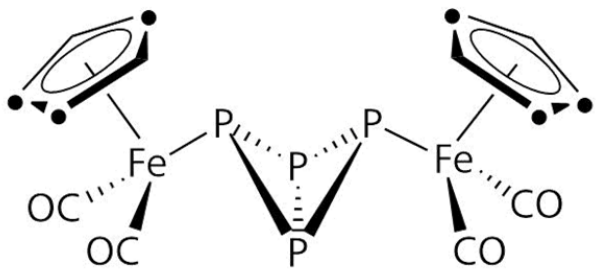

$\bullet=\mathrm{C}^{\mathrm{t}} \mathrm{Bu}$

Scheme 1. Selected compounds with a tetraphosphabicyclo[1.1.0] unit $[6,7,16]$.

That way, new cationic polyphosphorus compounds with catena [17-22], ring [22-24] or cage $[16,22,25]$ units could be synthesized, in particular by Burford and Weigand, who observed the stepwise opening of the P-P bonds of the $\mathrm{P}_{4}$ tetrahedron by insertion of $\left[\mathrm{R}_{2} \mathrm{P}\right]^{+}$ in a solvent-free reaction set up to the cationic cage compounds $\left[\mathrm{Ph}_{2} \mathrm{P}_{5}\right]^{+}(\mathrm{II}),\left[\mathrm{Ph}_{4} \mathrm{P}_{6}\right]^{2+}$ and $\left[\mathrm{Ph}_{6} \mathrm{P}_{7}\right]^{3+}$, respectively [16]. Besides $\mathrm{P}_{4}$, the tetrahedral complex $\left[\mathrm{Cp}^{\prime \prime \prime} \mathrm{Ni}\left(\eta^{3}-\mathrm{P}_{3}\right)\right]$ also reacts with phosphenium cations by insertion into one P-P bond [26]. In contrast, [Cp* $\left.\mathrm{Fe}\left(\eta^{5}-\mathrm{P}_{5}\right)\right]$ reacts with main group electrophiles, such as, for instance, $\mathrm{H}^{+}$or $\mathrm{CH}_{3}{ }^{+}$with the formation of a P-E bond [27]. Our preliminary studies have shown that 1 reacts with $\mathrm{HBF}_{4}$, leading to the protonation of one of the wing tip phosphorus atoms [12]. Therefore, the question arises as to whether the reaction of $\mathbf{1}$ with phosphenium cations leads to a simple coordination as observed for some transition metal fragments leading to type I complexes or to the insertion into one of the P-P bonds as reported for white phosphorus or $\left[\mathrm{Cp}^{\prime \prime \prime} \mathrm{Ni}\left(\eta^{3}-\mathrm{P}_{3}\right)\right]$, respectively. Furthermore, cations of the type $\left[\mathrm{R}_{2} \mathrm{E}\right]^{+}$are not only known for phosphorus but also for the heavier homologue arsenic [28-30], yet no studies on the reactivity towards polyphosphorus compounds or white phosphorus are known. Herein, we report on the reactivity of $\mathbf{1}$ towards in situ generated phosphenium and arsenium cations $\left[\mathrm{R}_{2} \mathrm{E}\right]^{+}(\mathrm{E}=\mathrm{P}$, As) leading to short-lived insertion and coordination products at low temperatures, which react further at room temperature to a cyclo- $\mathrm{P}_{5}$ unit in the case of $\mathrm{E}=\mathrm{P}$ and to a compound featuring the rarely observed tetracyclo[3.3.0.0 $\left.0^{2,7} \cdot 0^{3,6}\right]$ octaphosphaoctane entity in the case of $\mathrm{E}=$ As.

\section{Results}

\subsection{Reactions of $\mathbf{1}$ with $\left[\mathrm{Ph}_{2} \mathrm{P}\right]^{+}[\mathrm{A}]^{-}$}

The complex $\left[\left\{\mathrm{Cp}^{\prime \prime \prime} \mathrm{Fe}(\mathrm{CO})_{2}\right\}_{2}\left(\mu, \eta^{1: 1}-\mathrm{P}_{4}\right)\right](\mathbf{1})$ readily reacts with in situ generated diphenyl phosphenium salts generated from $\mathrm{Ph}_{2} \mathrm{PCl}$ and $\mathrm{Tl}[\mathrm{A}]\left([\mathrm{A}]^{-}=[\mathrm{OTf}]^{-}=\left[\mathrm{O}_{3} \mathrm{SCF}_{3}\right]^{-}\right.$, $\left[\mathrm{PF}_{6}\right]^{-}$) in ortho-difluorobenzene (o-DFB) at room temperature. In the ${ }^{31} \mathrm{P}\left\{{ }^{1} \mathrm{H}\right\} \mathrm{NMR}$ spectrum of the reaction solution of $\left[\left\{\mathrm{Cp}^{\prime \prime \prime} \mathrm{Fe}(\mathrm{CO})_{2}\right\}_{2}\left(\mu, \eta^{1: 1}-\mathrm{P}_{4}\right)\right](\mathbf{1})$ with $\mathrm{Ph}_{2} \mathrm{PCl}$ and $\mathrm{Tl}\left[\mathrm{PF}_{6}\right]$, two sets of signals are visible for two main products-a well-resolved ADEMX spin system [31] corresponding to the cyclo- $\mathrm{P}_{5}$ unit of the novel compound $\left[\left\{\mathrm{Cp}^{\prime \prime \prime} \mathrm{Fe}\right\}\left(\mu, \eta^{4: 1}\right.\right.$ $\left.\left.\mathrm{P}_{5} \mathrm{Ph}_{2}\right)\left\{\mathrm{Cp}^{\prime \prime \prime} \mathrm{Fe}(\mathrm{CO})_{2}\right\}\right]\left[\mathrm{PF}_{6}\right]$ (4, Scheme 2) and a set of broad signals with one resolved multiplet. This set of signals cannot be definitely attributed to a specific compound, but very probably contains a phosphorus core similar to that of $\mathbf{2 a}$. After removal of the solvent from the reaction mixture and extraction of the residue with a mixture of toluene and diethylether, some tiny needles of 4 could be obtained, very weakly scattering in the routine single crystal X-ray diffraction experiment but suitable for the diffraction study using high-flux synchrotron radiation (see Materials and Methods, Figure 1b). The remaining red oil was dissolved in a mixture of o-DFB and pentane. By storing the saturated solution at $-30^{\circ} \mathrm{C}$, a few red crystals of $\left[\left\{\mathrm{Cp}^{\prime \prime \prime} \mathrm{Fe}(\mathrm{CO})_{2}\right\}_{2}\left(\mu, \eta^{1: 1}-\mathrm{P}_{5} \mathrm{Ph}_{2}\right)\right]\left[\mathrm{PF}_{6}\right](3 \mathbf{a})$, suitable for X-ray diffraction analysis, could be obtained (Figure 1a). All attempts to isolate 2a failed, due to its high instability and presumably to its rearrangement to $3 \mathbf{a}$. The presumed rearrangement of $\mathbf{2} \mathbf{a}$ to $\mathbf{3 a}$ is also supported by DFT calculations (vide infra). 

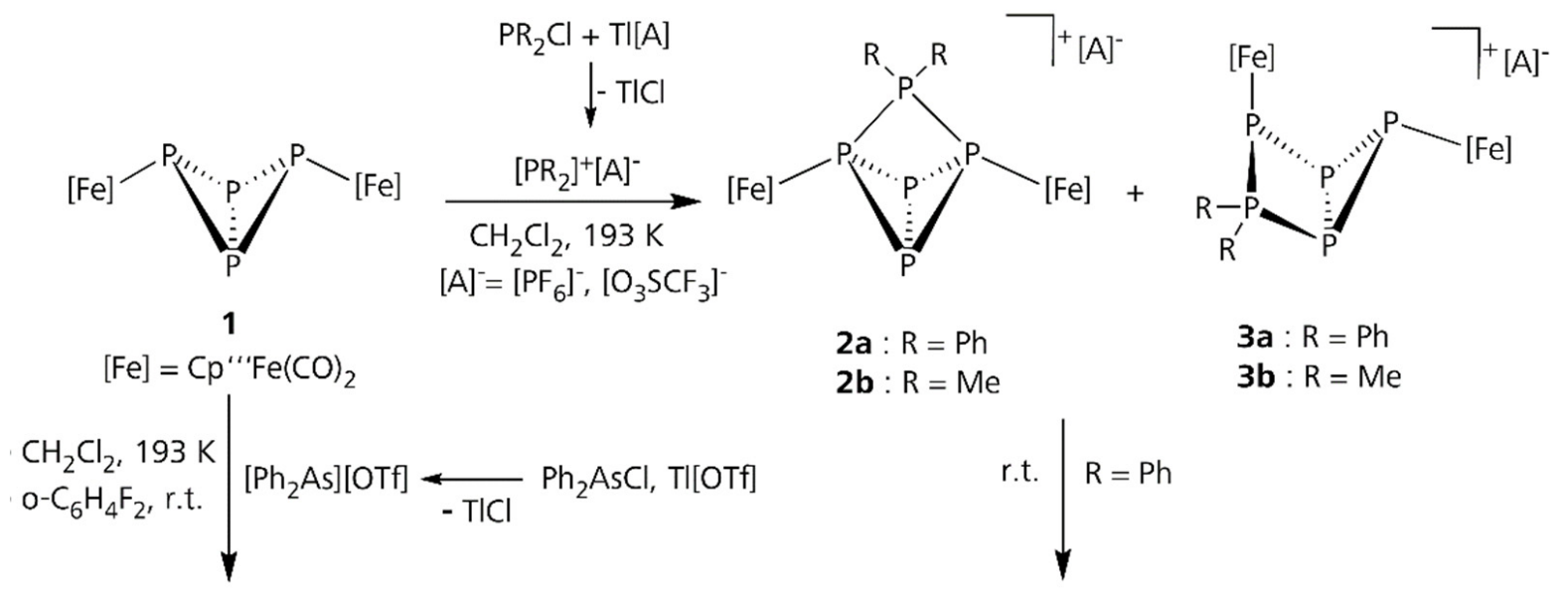

r.t. $\downarrow R=P h$
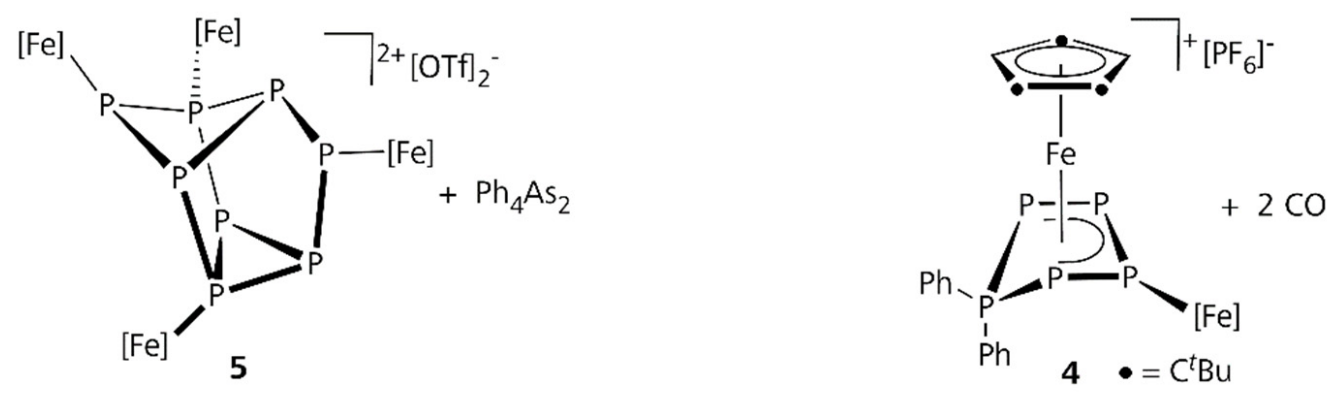

Scheme 2. Reaction of $\mathbf{1}$ with in situ generated phosphenium and arsenium ions.

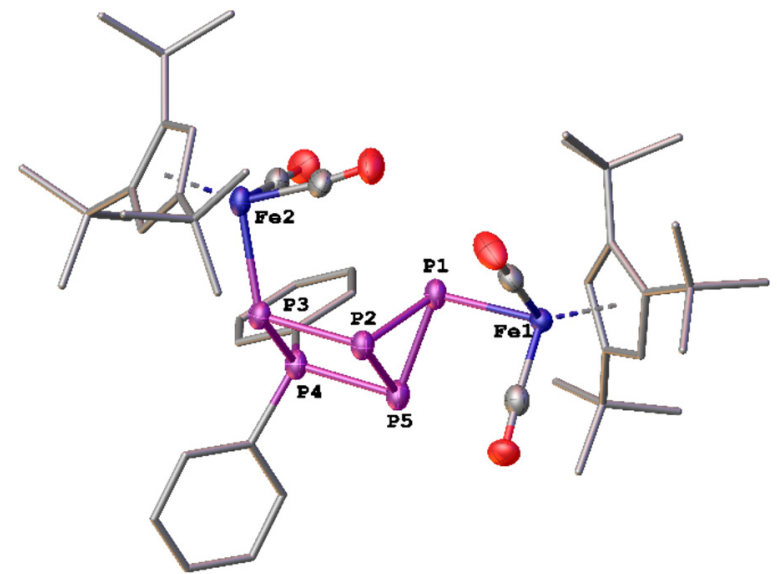

(a)

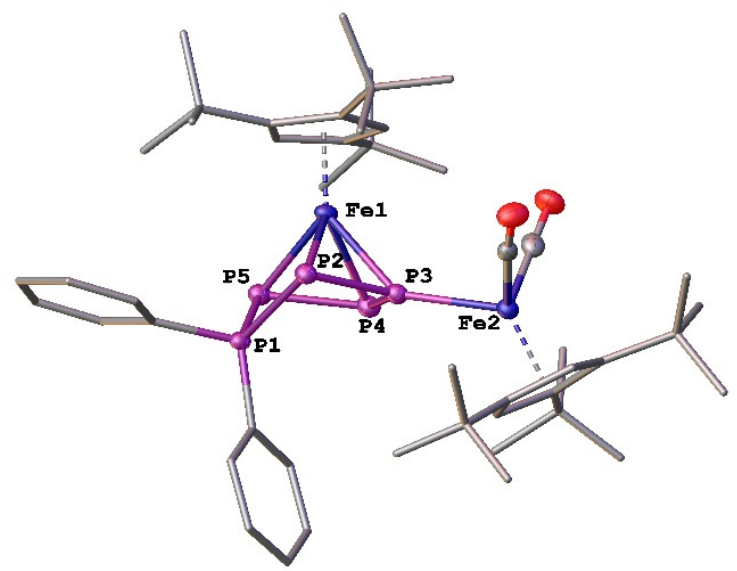

(b)

Figure 1. Cationic parts of the molecular structures of $3 \mathbf{a}(\mathbf{a})$ and $4(\mathbf{b})$, respectively, in the solid state. Hydrogen atoms, solvent molecules and counter ions are omitted for clarity. Selected bond lengths ( $⿱$ A) for 3a-Fe1-P1 2.3162(12), Fe2P3 2.3004(15), P1-P5 2.2010(18), P2-P1 2.1971(15), P2-P5 2.2546(17), P3-P2 2.2305(15), P3-P4 2.2128(17), P4-P5 2.1974(16). Selected bond lengths (Å) for 4-Fe1-P3 2.2925(7), Fe1-P5 2.3422(7), Fe1-P4 2.3517(8), Fe1-P2 2.3610(8), Fe2-P3 2.2567(7), P1-P52.1590(9), P1-P2 2.1761(9), P2-P3 2.1293(9), P3-P4 2.1337(9), P4-P5 2.1322(10).

In order to identify the intermediates which are formed in the reaction of 1 with $\left[\mathrm{R}_{2} \mathrm{P}\right]^{+}$ and to further investigate the nature of the dynamic behaviour in solution, ${ }^{31} \mathrm{P}\left\{{ }^{1} \mathrm{H}\right\} \mathrm{NMR}$ spectroscopic studies were performed at low temperatures. For this purpose, corresponding reaction samples were prepared in dichloromethane at $193 \mathrm{~K}$ and kept at this temperature, without allowing them to warm up. The reaction solutions of $\mathbf{1}$ with $\left[\mathrm{Ph}_{2} \mathrm{P}\right][\mathrm{OTf}]$ showed two independent spin systems, ADMVX and ADMQX, with one multiplet of each spin system overlying. The connectivity of the phosphorus cores of the two spin systems could be determined by ${ }^{31} \mathrm{P}^{31} \mathrm{P}$ COSY NMR (homonuclear correlation spectroscopy) experiments 
and iterative simulations (Figure 2 and Supplementary Materials). The ADMVX spin system can be attributed to $3 \mathbf{a}$, while the ADMQX spin system can very likely be attributed to $\mathbf{2 a}$. The ratio of $\mathbf{2 a}: 3 \mathbf{a}$ at $193 \mathrm{~K}$ was determined to be 5:2. Upon warming the sample, the signals of both spin systems broaden and collapse into each other at $253 \mathrm{~K}$ to give only one set of broad signals (four broad ones and one relatively sharp one, Figure 3). A further increase of the temperature only leads to a further broadening of the signals. Finally, at $300 \mathrm{~K}$, four broad signals and one well-resolved one are detected in the ${ }^{31} \mathrm{P}\left\{{ }^{1} \mathrm{H}\right\} \mathrm{NMR}$ spectrum. These findings show that $2 \mathbf{a}$ and $3 \mathbf{a}$ are formed in the first step of the reaction of 1 with $\left[\mathrm{Ph}_{2} \mathrm{P}\right]^{+}$, at temperatures above $253 \mathrm{~K}$, however, they are in an equilibrium. The fact that one of the signals remains unaffected by the broadening within the whole temperature range, which we tentatively attribute to the $\mathrm{Ph}_{2} \mathrm{P}$ unit in $\mathbf{2 a}$, indicates that, at room temperature, 2a might be the major component and that the $\mathrm{Ph}_{2} \mathrm{P}$ unit is interchanged between the two wingtip phosphorus atoms in a fast process on the NMR time scale. A similar behaviour was observed for $\left[\left(\mathrm{Cp}^{\mathrm{Ar} N i}\right)_{2}\left(\eta^{3: 3}-\mathrm{P}_{5} \mathrm{R}_{2}\right)\right]\left[\mathrm{GaCl}_{4}\right]\left(\mathrm{Cp}^{\mathrm{Ar}}=\mathrm{C}_{5}\left(\mathrm{C}_{6} \mathrm{H}_{4}-4\right.\right.$ $\mathrm{Et})_{5}, \mathrm{R}=\mathrm{iPr}$ and $\left.2,4,6-\mathrm{Me}_{3} \mathrm{C}_{6} \mathrm{H}_{2}\right)[32]$ as well as for $\left[\left\{\mathrm{Cp}^{\prime \prime \prime} \mathrm{Fe}(\mathrm{CO})_{2}\right\}_{2}\left(\mu, \eta^{1: 1}-\mathrm{P}_{4} \mathrm{H}\right)\right]^{+}$一the protonated complex of $\mathbf{1}$ [12]. According to DFT calculations in $2 \mathrm{a}$, the $\mathrm{Ph}_{2} \mathrm{P}$ unit binds only to one wing-tip phosphorus atom (vide infra). Increasing the temperature above 300 $\mathrm{K}$ leads to a rapid decomposition in dichloromethane. Unfortunately, o-DFB is not suitable for performing the experiments at $193 \mathrm{~K}$ due to its relatively high point of solidification (239 K).

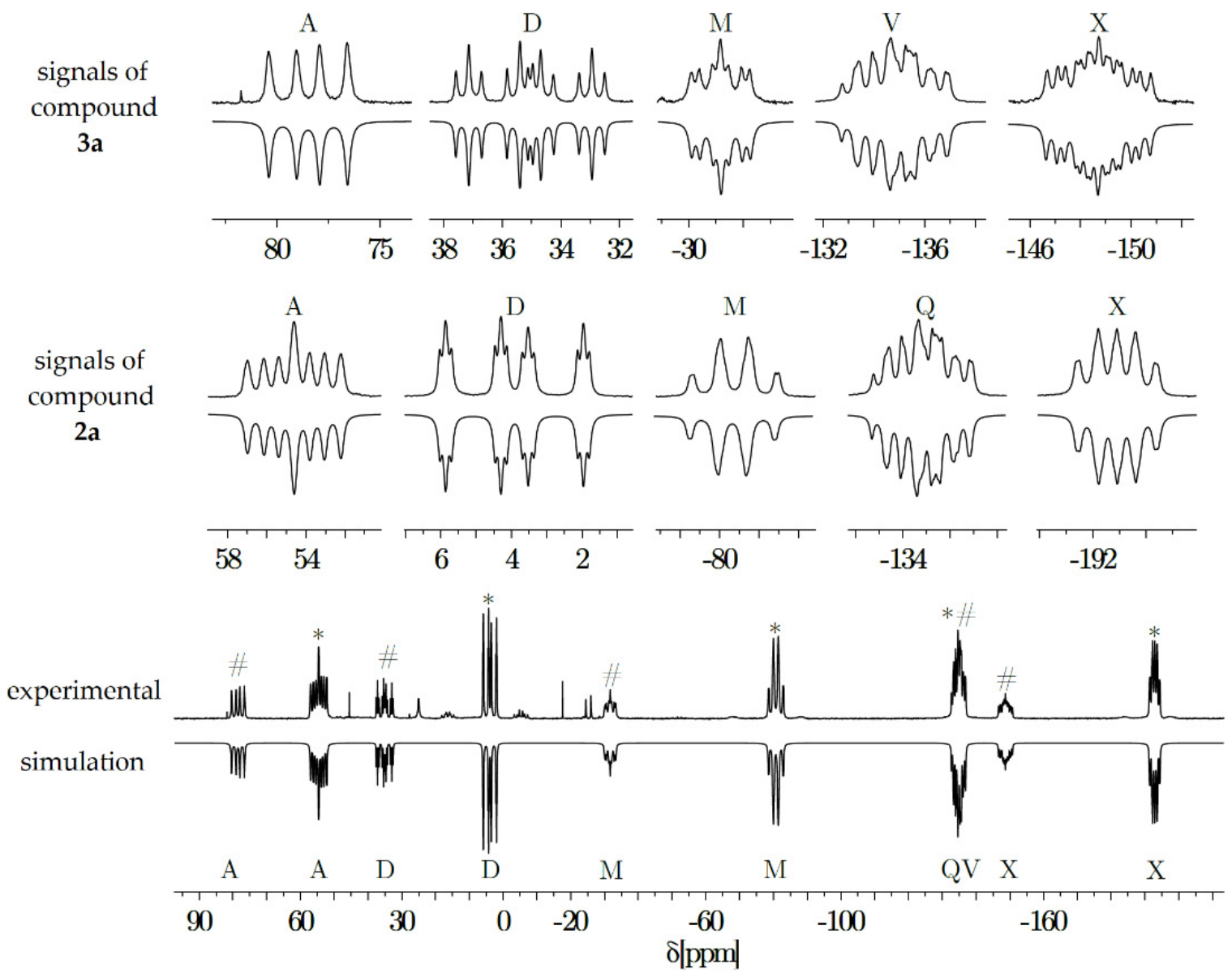

Figure 2. Experimental and simulated ${ }^{31} \mathrm{P}\left\{{ }^{1} \mathrm{H}\right\}$ NMR spectrum at $193 \mathrm{~K}$ of compounds $\mathbf{2 a}$ and $\mathbf{3 a}(*=\mathbf{2 a}$, \# = 3a). The multiplet $\mathrm{Q} / \mathrm{V}$ is the result of two overlapping multiplets from the two different spin systems. 

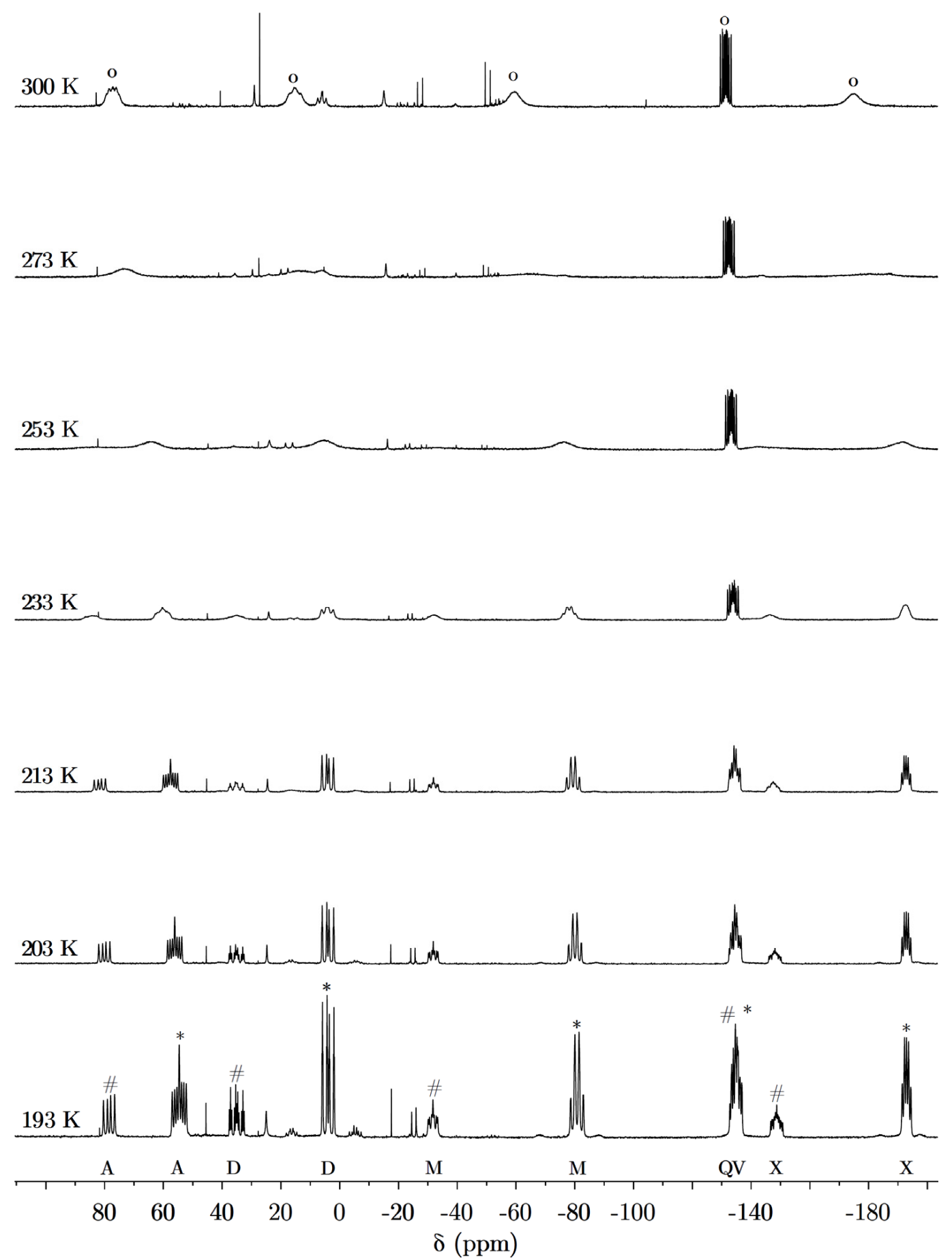

Figure 3. ${ }^{31} \mathrm{P}\left\{{ }^{1} \mathrm{H}\right\}$ VT NMR spectra of the reaction solution of $\mathbf{1}$ with $\left[\mathrm{Ph}_{2} \mathrm{P}\right][\mathrm{OTf}]$ in $\mathrm{CD}_{2} \mathrm{Cl}_{2}(*=\mathbf{2 a}$, \#= , o = broad signals at r.t.).

By the reaction of $\left[\mathrm{Me}_{2} \mathrm{P}\right][\mathrm{OTf}]$, generated in situ from $\mathrm{Me}_{2} \mathrm{PCl}$ and $\mathrm{Tl}[\mathrm{OTf}]$, with $\mathbf{1}$ at $193 \mathrm{~K}$ in dichloromethane, the two products $\mathbf{2 b}$ and $\mathbf{3 b}$ could be identified in the ${ }^{31} \mathrm{P}$ $\left\{{ }^{1} \mathrm{H}\right\}$ NMR spectrum at $193 \mathrm{~K}$. Compound $\mathbf{2 b}$ reveals an ADMQX and $\mathbf{3 b}$ an ABMWX spin system. The phosphorus cores of both these compounds could be determined by iterative simulation as well as by ${ }^{31} \mathrm{P}-{ }^{31} \mathrm{P}$ COSY NMR experiments, showing the same connectivity as $\mathbf{2} \mathbf{a}$ and $\mathbf{3 a}$. By warming the NMR sample to room temperature for the time of one measurement and subsequent cooling to $193 \mathrm{~K}$, besides signs of decomposition, the relative ratio of the two products in solution changes in favour of the insertion product $\mathbf{3 b} \mathbf{b} \mathbf{3} \mathbf{b}: \mathbf{2 b}=$ 4:1 before r.t., 10:1 after). This suggests that either $\mathbf{2} \mathbf{b}$ is less stable than $\mathbf{3} \mathbf{b}$ and decomposes 
faster or that both compounds exist in a dynamic equilibrium at room temperature and the formation of $\mathbf{3 b}$ is favoured as being the thermodynamically more stable product. For the structurally similar products $\mathbf{2} \mathbf{a}$ and $\mathbf{3 a}$, we assume a similar behaviour (vide supra; cf. Supplementary Materials).

\subsection{Reactions of $\mathbf{1}$ with $\left[\mathrm{Ph}_{2} \mathrm{As}\right]^{+}[\mathrm{OTf}]^{-}$}

If 1 is reacted with [ $\mathrm{Ph}_{2} \mathrm{As}$ ][OTf] at $193 \mathrm{~K}$, generated in situ from $\mathrm{Ph}_{2} \mathrm{AsCl}$ and $\mathrm{Tl}[\mathrm{OTf}]$ in dichloromethane, two compounds showing $\mathrm{ABX}_{2}$ spin systems at room temperature and an ABWX for one of the compounds at $193 \mathrm{~K}$ are observed in the ${ }^{31} \mathrm{P}\left\{{ }^{1} \mathrm{H}\right\} \mathrm{NMR}$ spectrum of the reaction solution. Iterative simulation enabled the determination of the connectivity of the phosphorus cores. However, the structural motifs of these compounds could not be undoubtedly determined, since the connectivity of the $\mathrm{Ph}_{2} \mathrm{As}$ fragment could not be ascertained from the NMR data. Due to their instability as well as their high solubility, these compounds could not be isolated despite several attempts. The reaction solutions in dichloromethane are only stable for a few hours at room temperature. If the reaction is performed at $193 \mathrm{~K}$, the dichloromethane removed at $-60{ }^{\circ} \mathrm{C}$ and the resulting dark red oil is redissolved in a mixture of o-DFB and pentane (1:1), single crystals of the complex $\left[\left\{\mathrm{Cp}^{\prime \prime \prime} \mathrm{Fe}(\mathrm{CO})_{2}\right\}_{4}\left(\mu_{4}, \eta^{1: 1: 1: 1}-\mathrm{P}_{8}\right)\right][\mathrm{OTf}]_{2}(5)$ can be obtained (Scheme 2 and Figure 4). Compound 5 contains a tetracyclo[3.3.0.0 $\left.0^{2,7} \cdot 0^{3,6}\right]$-octaphosphaoctane unit which is rarely observed and represents an unexpected isomer for a $\mathrm{P}_{8}$ core. The only other compound reported so far containing a similar $\mathrm{P}_{8}$ core is $\left[(\mathrm{DDP}) \mathrm{GaBr}_{2} \mathrm{P}_{8}\right]$ (DDP $=(2,6-$ diisopropylphenyl)(4-((2,6-diisopropylphenyl)imino)pent-2-en-2-yl)amide) [33]. The most common $\mathrm{P}_{8}$ motif is the realgar-type motif which can also be viewed as a subunit of Hittorf's phosphorus and considered as an important building block of hierarchical structures of elemental phosphorus [34-41].

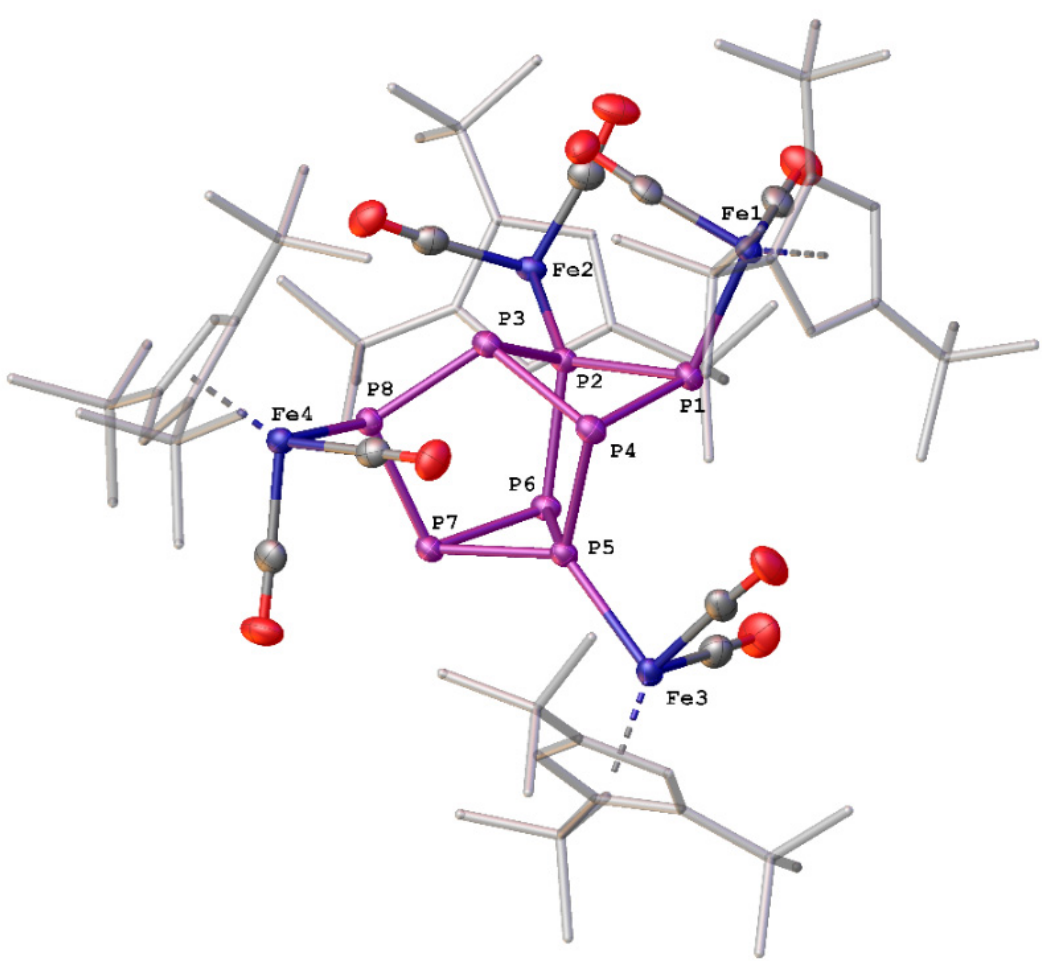

Figure 4. Cationic part of the molecular structure of $\mathbf{5}$ in the solid state. Hydrogen atoms, solvent molecules and counter ions are omitted for more clarity. Selected bond lengths ( $\mathrm{A})$-Fe4-P8 2.2756(5), Fe3-P5 2.2468(5), Fe2-P2 2.2587(5), Fe1-P1 2.3040(5), P5-P6 2.2115(7), P5-P7 2.1916(7), P5-P4 2.2134(7), P2-P3 2.1890(7), P2-P6 2.2713(6), P2-P1 2.2758(7), P3-P8 2.1612(7), P3-P4 2.2062(7), P6-P7 2.2071(6), P8-P7 2.1925(7), P4-P1 2.2402(7). 


\section{Discussion}

The structural motif in the crystal structure of 3a is identical with the postulated bicyclo[2.1.0]pentaphosphapentane framework from the low temperature NMR experiments. This structural motif is the result of the insertion of $\left[\mathrm{Ph}_{2} \mathrm{P}\right]^{+}$into one of the edge-P-P bonds in 1. The P-P bond lengths in $3 \mathrm{a}$ lie in the expected range of P-P single bonds (average P-P distance in 3a: $2.215 \AA$ ) and compare well with the P-P bond lengths in 1 [7]. The threemembered ring built up by P1, P2 and P5 (Figure 1a) and the P2P3P4P5 four-membered ring are slightly distorted. The dihedral angle between the two rings is $99^{\circ}$ and therefore 1 is considerably more folded than $3 \mathbf{a}$ (fold angle $\left.80^{\circ}\right)$. The endo- $\left[\mathrm{Cp}^{\prime \prime \prime}(\mathrm{CO})_{2} \mathrm{Fe}\right]$ fragment of $\mathrm{Fe} 2$ as well as the fragment of Fe1, remaining in an exo-position as in 1, show a slightly shorter Fe-P bond distance (Fe1-P1 = 2.3162(12) $\AA$ and Fe2-P3 = 2.3004(15) $\AA$ ) compared with the Fe-P distances in 1 (Fe1-P1 is 2.355(3) $\AA$ and Fe2-P3 is 2.346(2) $\AA$ ). To the best of our knowledge, the only other compound containing a bicyclo[2.1.0]pentaphosphapentane core crystallographically characterized is the supersilylphosphine $\left(\mathrm{tBu}_{3} \mathrm{Si}\right)_{3} \mathrm{P}_{5}$ [42].

The formation of the cyclo- $\mathrm{P}_{5}$ unit in 4 (Figure $1 \mathrm{~b}$ ) is the result of the twofold decarbonylation of one iron center (probably Fe2) in 3a (Figure 1a) with a consequent opening of the P2-P6 bond. As an $\eta^{4}$-coordinating cyclo- $\mathrm{P}_{5}$ ligand with one phosphorus atom bent out of the plane, the cyclo- $\mathrm{P}_{5}$ unit in 4 can be compared to the known $\mathrm{P}_{5}$ ligand in $\left[\mathrm{K}(\mathrm{dme}) \mathrm{K}\left(\right.\right.$ dibenzo-[18]crown-6)][C $\left.\mathrm{p}^{*} \mathrm{Fe}\left(\eta^{4}-\mathrm{P}_{5}\right)\right]$ [43], the functionalized $\mathrm{P}_{5}$-ligands in $\left[\mathrm{Cp}^{*} \mathrm{Fe}\left(\eta^{4}-\mathrm{P}_{5} \mathrm{R}\right)\right]\left(\mathrm{R}=\mathrm{NMe}_{2}, \mathrm{PH}_{2}, \mathrm{CH}_{2} \mathrm{SiMe}_{3}\right)$ [44] or the cationic complex [Cp ${ }^{\mathrm{Ar}} \mathrm{Co}\left(\eta^{4}-\right.$ $\left.\left.\mathrm{P}_{5} \mathrm{R}_{2}\right)\right]\left[\mathrm{GaCl}_{4}\right]\left(\mathrm{Ar}=\mathrm{C}_{5}\left(\mathrm{C}_{6} \mathrm{H}_{4}-4-\mathrm{Et}\right)_{5}, \mathrm{R}=\mathrm{iPr}\right.$ and $\left.\mathrm{Cy}\right)$ [32], but differs in bond lengths and angles due to its cationic character and its coordination of a second iron fragment. This is also the reason why 4 shows a complex ADEMX spin system for an asymmetric $P_{5}$ moiety of magnetically inequivalent phosphorus atoms instead of an $\mathrm{AMM}^{\prime} \mathrm{XX}^{\prime}$ spin system as expected for the aforementioned compounds. In 4 , the bond distances of the $\mathrm{Ph}_{2} \mathrm{P}$ fragment P1-P2 (2.1761(9) $\AA$ ) and P1-P5 (2.1590(9) $\AA$ ) to the rest of the $\mathrm{P}_{5}$ moiety are noticeably different. The other bond distances are significantly shorter, with P2-P3 being the shortest one (2.1293(9) $\AA$ ). Apart from the lack of symmetry, the bond lengths are also in agreement with the known cyclo- $\mathrm{P}_{5}$ moieties mentioned above.

According to the variable temperature NMR experiments, the reaction mixtures of 1 with phosphenium ions turned out to be stable only up to $-60{ }^{\circ} \mathrm{C}$ in dichloromethane. By changing the solvent and the anion in order to find a reaction set up stable enough to obtain the single crystals of $\mathbf{3 a}$ and 4 , respectively, the cationic parts of $\mathbf{2 a}$ and $3 a$ were found to be more stable in o-DFB, using stronger coordinating counter ions such as [OTf $]^{-}$. Using weakly coordinating anions such as $[\mathrm{TEF}]^{-}\left([\mathrm{TEF}]^{-}=\left[\mathrm{Al}\left(\mathrm{OC}\left(\mathrm{CF}_{3}\right)_{3}\right)_{4}\right]^{-}\right)$[45] leads to less stable reaction mixtures or to the formation of larger quantities of 4 in dichloromethane. Using o-DFB and the $\left[\mathrm{PF}_{6}\right]^{-}$anion, the products were stable enough for crystallization, and small amounts of single crystals of $\mathbf{3 a}$ and 4 suitable for X-ray diffraction studies could be obtained. This leads to the presumption that the cationic parts of $\mathbf{2 a}$ and $3 \mathbf{a}$ are not stable enough without being stabilized by a coordinating anion so that at least $3 a$ undergoes two consecutive decarbonylations to form 4 (Scheme 3). The decarbonylation of $\left[\left\{\mathrm{Cp}^{\prime \prime} \mathrm{Fe}(\mathrm{CO})_{2}\right\}_{2}\left(\mu, \eta^{1: 1}-\mathrm{P}_{4}\right)\right]$ leading to $\left[\left\{\mathrm{Cp}^{\prime \prime} \mathrm{Fe}(\mathrm{CO})_{2}\right\}\left(\mu, \eta^{1: 2}-\mathrm{P}_{4}\right)\left\{\mathrm{Cp} \mathrm{p}^{\prime \prime} \mathrm{Fe}(\mathrm{CO})\right\}\right]$ was reported [46]. To clarify if 4 was formed via the decarbonylation of 3a, DFT calculations at the BP86/def2-SVP level were performed. The results show that the attack of the phosphenium ion is exergonic, while the first decarbonylation of $\mathbf{3}$ is noticeably endergonic. The fact that the second decarbonylation is exergonic would explain why the product from the first decarbonylation of 3a could not be detected, except in the ESI-MS spectra of freshly prepared reaction solutions. At room temperature, the reaction energy released from the formation of 3a was large enough to trigger the first decarbonylation to some degree, which would explain the formation of 4 at room temperature as well as the absence of 4 when reaction solutions are prepared at low temperatures and with stabilizing anions. It is uncertain so far whether $2 \mathrm{a}$ undergoes a twofold decarbonylation at room temperature as well. Since ${ }^{31} \mathbf{P}$ NMR experiments showed that $\mathbf{2} \mathbf{b}$ and $\mathbf{3 b}$ are not equally stable upon varying the temperature and because $\mathbf{2} \mathbf{a}$ and $\mathbf{3} \mathbf{a}$ exhibited a similar behaviour, DFT calculations 
were performed on $\mathbf{2 a}$. Their results also show that the cationic part in $3 \mathbf{a}$ is $27 \mathrm{~kJ} / \mathrm{mol}$ lower in energy than $\mathbf{2 a}$.
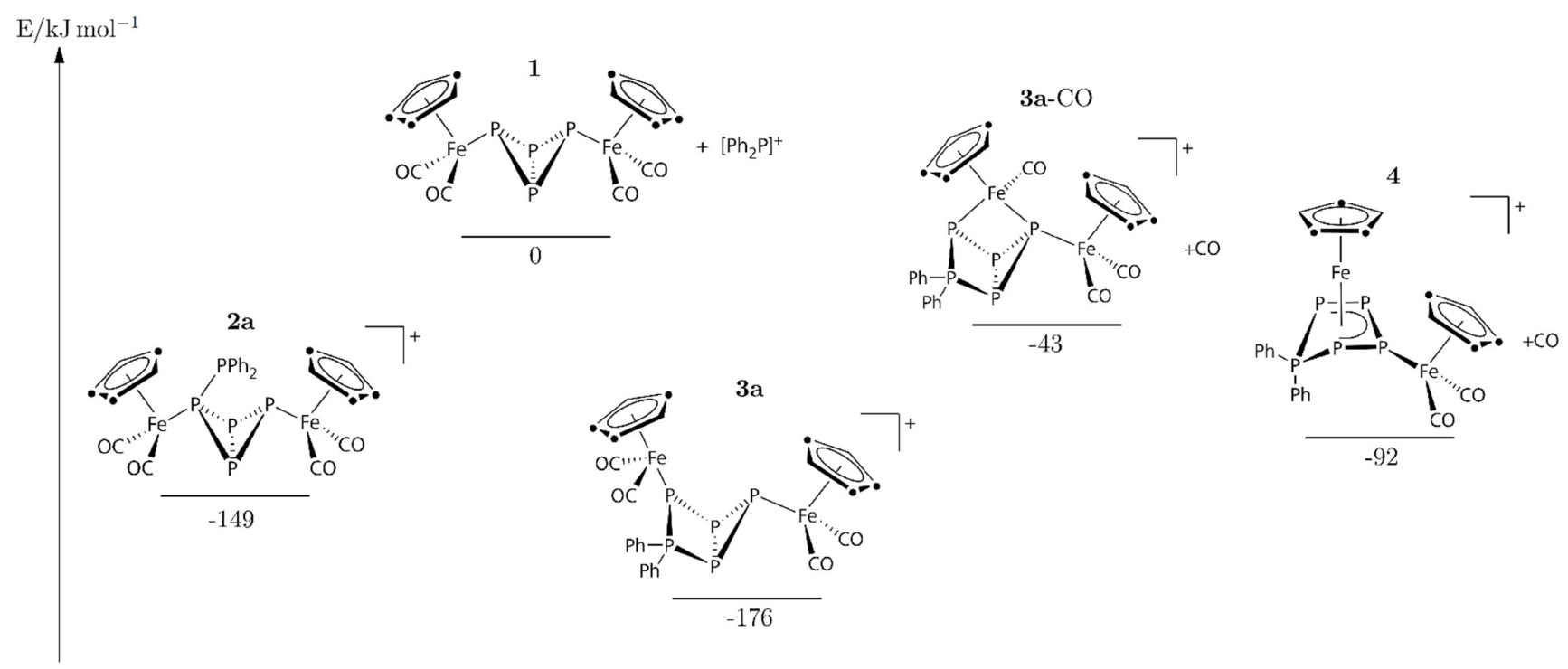

Scheme 3. Relative energies of starting material 1 and $\left[\mathrm{PPh}_{2}\right]^{+}, 3 \mathbf{a}$ and its decarbonylation to 4 on the BP86/def2-SVP level.

The variation of chlorophosphine to dimethyl-, dicyclohexyl-, ditertbutyl- or bisdiethylamino-chlorophosphine or bis-benzo-chlorophosphole only leads to satisfactory results in the case of dimethyl-chlorophosphine giving similar structural motifs in the low-temperature ${ }^{31} \mathrm{P}$ NMR experiments as the phenyl-substituted derivatives $\mathbf{2 a}$ and $\mathbf{3 a}$. Compounds $\mathbf{2} \mathbf{b}$ and $\mathbf{3} \mathbf{b}$ show an even higher sensitivity than the phenyl-substituted compounds. The products formed by the coordination of $\left[\mathrm{Ph}_{2} \mathrm{As}\right]^{+}$to 1 are even less stable and convert to compound 5 and $\mathrm{Ph}_{4} \mathrm{As}_{2}$. Compound 5 can formally be described as the dimer of the radical cation of $\mathbf{1}$. As already mentioned, the $P_{8}$ unit in $\mathbf{5}$ is a very rare example of a tetracyclo[3.3.0.0 $0^{2,7} \cdot 0^{3,6}$ ]octaphosphaoctane core, which had only been observed in [(DDP) $\mathrm{GaBr}_{2} \mathrm{P}_{8}$ ] [33]. The P-P bond lengths in the solid-state structure of 5 are very similar and vary from 2.1612(7) $\AA$ (P3-P8) to 2.2758(7) $\AA$ (P2-P1). The ${ }^{31} \mathrm{P}$ NMR spectrum of 5 shows six broadened and two sharp multiplets of an AEGHMQTX spin system of eight chemically inequivalent phosphorus atoms. In order to assign the signals properly to the corresponding phosphorus atoms in the solid-state structure, we conducted variable temperature NMR experiments ( 193 to $300 \mathrm{~K}$, Supplementary Materials). These experiments did not result in freezing any dynamic process in solution to the extent that the spin system is resolved well enough on the NMR time scale for iterative simulation. However, the couplings were resolved well enough for ${ }^{31} \mathrm{P} \_-{ }^{31} \mathrm{P}$ COSY NMR measurements from which the connectivity of the $\mathrm{P}_{8}$ moiety in $\mathbf{5}$ could be determined. The general principle of formally oxidizing compounds by attacking the diphenylarsenium cations and consequently forming tetraphenyldiarsine as a thermodynamic driving force should be applicable to electron-rich starting materials other than $\mathbf{1}$ and prove to be a good starting point for future studies.

\section{Materials and Methods}

\subsection{General Techniques and Materials}

All manipulations were performed using standard Schlenk techniques on a dual manifold Schlenk line or a glove box under an atmosphere of dry argon. Traces of oxygen in the inert gas were removed by passing it over a BASF R 3-11 $\left(\mathrm{CuO} / \mathrm{MgSiO}_{3}\right)$ catalyst. Residual moisture in the inert gas was removed, by passing it through concentrated $\mathrm{H}_{2} \mathrm{SO}_{4}$, orange gel and sicapent on dried pumice stone. All glassware was vigorously heated in dynamic vacuum before use and any Teflon tubing was stored in an oven at 
$443 \mathrm{~K}$. Dichloromethane, toluene, hexane and pentane were purified and dried by the solvent purification system SPS-800 from MBRAUN (Garching, Germany). Deuterated solvents and o-DFB were dried and distilled over $\mathrm{CaH}_{2}$. All solvents were stored over a molecular sieve, which was dried in a dynamic vacuum at $623 \mathrm{~K} . \mathrm{Ph}_{2} \mathrm{PCl}, \mathrm{Me}_{2} \mathrm{PCl}, \mathrm{TlPF}_{6}$ and TlOTf were obtained from Sigma Aldrich (St. Louis, MO, USA) and used without further purification, except for $\mathrm{Ph}_{2} \mathrm{PCl}$, which was distilled prior to use. $\mathrm{Me}_{2} \mathrm{PCl}$ and its standard solutions were stored and handled at temperatures below $277 \mathrm{~K}$ at all times. $\left[\left\{\mathrm{Cp}^{\prime \prime \prime} \mathrm{Fe}(\mathrm{CO})_{2}\right\}_{2}\left(\mu, \eta^{1: 1}-\mathrm{P}_{4}\right)\right][8]$ and $\mathrm{Ph}_{2} \mathrm{AsCl}[47]$ were synthesized according to literature procedures. NMR spectra were measured with a Bruker Avance 400 (Billerica, MA, USA) $\left({ }^{1} \mathrm{H}: 400.13 \mathrm{MHz} ;{ }^{13} \mathrm{C}: 100.61 \mathrm{MHz} ;{ }^{31} \mathrm{P}: 161.97 \mathrm{MHz}\right)$ using special NMR tubes with a screw cap or a J. Young valve. Any working steps preparing samples for measurement at $193 \mathrm{~K}$ were performed at this temperature and the samples were stored at $193 \mathrm{~K}$ until measured. The spin systems of the ${ }^{31} \mathrm{P}$ NMR spectra were simulated with the DAISY package in TopSpin 3.2 from Bruker (Billerica, MA, USA) using the data from 2D NMR spectra to assign the multiplets to the corresponding compounds and obtain first insights into the connectivity of the phosphorus framework. All coupling constants are given in $\mathrm{Hz}$. The diffraction from a tiny needle-shaped single crystal of 4 , of $4 \times 10 \times 50 \mu^{3}$ in size, was collected at $80 \mathrm{~K}$ on the P11 beamline at PETRAIII synchrotron at DESY (Hamburg, Germany) [48], using the high-flux X-ray beam focused and collimated down to $50 \mu \mathrm{m}$ in $\varnothing$ to reduce the background and to significantly improve the intensity-to-noise ratio.

\subsection{Reaction of 1 with in Situ Generated $\left[\mathrm{Ph}_{2} P\right]\left[P F_{6}\right]$ at Room Temperature}

To a solution of $\left[\left\{\mathrm{Cp}^{\prime \prime \prime} \mathrm{Fe}(\mathrm{CO})_{2}\right\}_{2}\left(\mu, \eta^{1: 1}-\mathrm{P}_{4}\right)\right](\mathbf{1})(82 \mathrm{mg}, 0.1 \mathrm{mmol})$ and $\mathrm{TlPF}_{6}(36 \mathrm{mg}$, $0.103 \mathrm{mmol})$ in $5 \mathrm{~mL}$ o-DFB, a standard solution of $\mathrm{Ph}_{2} \mathrm{PCl}$ in toluene $\left(\mathrm{c}=0.2 \mathrm{mmol} \mathrm{mL}^{-1}\right)$ was added at room temperature. While stirring for $12 \mathrm{~h}$, a colourless precipitate of $\mathrm{TlCl}$ was formed from which a dark red solution was decanted. The solvent was carefully removed and the resulting red oil extracted with a mixture of diethyl ether and toluene (10:1, $\mathrm{Et}_{2} \mathrm{O}$ :toluene) (three times with $5 \mathrm{~mL}$ ). The pale red diethyl ether/toluene solution was stored at $277 \mathrm{~K}$ for 2 months. Some extremely fine needles of 4 suitable for diffraction with synchrotron radiation were retrieved from the flask. The residual oil was redissolved in o-DFB at room temperature and, upon addition of pentane at $243 \mathrm{~K}$, the formation of a dark red oil could be observed. After storage at room temperature until the oil redissolved, the flask was stored at $243 \mathrm{~K}$ for crystallization. After one month, a few crystals of 3a suitable for X-ray diffraction studies could be obtained. The amounts of crystalline 4 and 3a were too small to estimate the yield of the isolated products. ${ }^{31} \mathrm{P}\left\{{ }^{1} \mathrm{H}\right\}$ NMR spectra of the reaction solution show full conversion of $1 .{ }^{1} \mathrm{H}$ NMR of reac. mix.- $\left(\mathrm{CD}_{2} \mathrm{Cl}_{2}, 300 \mathrm{~K}\right)$ :

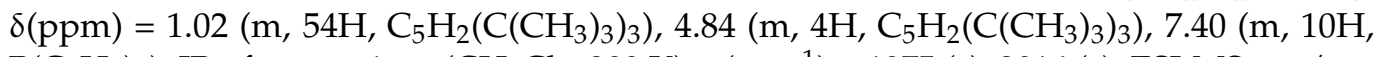
$\left.\mathrm{P}\left(\mathrm{C}_{6} \mathrm{H}_{5}\right)_{2}\right)$; IR of reac. mix.- $\left(\mathrm{CH}_{2} \mathrm{Cl}_{2}, 300 \mathrm{~K}\right): v\left(\mathrm{~cm}^{-1}\right)=1975$ (s), 2016 (s); ESI-MS- $m / z=$ $1001\left([\mathrm{M}]^{+}\right), 971\left([\mathrm{M}]^{+}-\mathrm{CO}\right), 943\left([\mathrm{M}]^{+}-2 \mathrm{CO}\right) ;{ }^{31} \mathrm{P}\left\{{ }^{1} \mathrm{H}\right\} \mathrm{NMR}$ of $4\left(\mathrm{CD}_{2} \mathrm{Cl}_{2}, 300 \mathrm{~K}\right)-\delta(\mathrm{ppm})$ $=210.8\left(\mathrm{~m}, \mathrm{P}_{\mathrm{A}}, \mathrm{J}_{\mathrm{PAPM}}=365,{ }^{1} \mathrm{~J} \mathrm{PAPX}=365,{ }^{2} \mathrm{~J}_{\mathrm{PAPD}}=26\right), 150.6\left(\mathrm{~m}, \mathrm{P}_{\mathrm{D}},{ }^{1} \mathrm{JPDPE}=415,{ }^{1} \mathrm{~J}\right.$ PDPX $\left.=370,{ }^{2} \mathrm{~J}_{\mathrm{PDPA}}=26,{ }^{2} \mathrm{~J} \mathrm{PDPM}=14\right), 125.4\left(\mathrm{~m}, \mathrm{Ph}_{2} \mathrm{P}_{\mathrm{E}},{ }^{1} \mathrm{~J}_{\mathrm{PEPD}}=415,{ }^{1} \mathrm{~J}_{\mathrm{PEPM}}=516,{ }^{2} \mathrm{~J}_{\mathrm{PEPX}}=11\right)$, $53.9\left(\mathrm{~m}, \mathrm{P}_{\mathrm{M}},{ }^{1} \mathrm{JPMP}_{\mathrm{PMP}}=365,{ }^{1} \mathrm{~J}_{\mathrm{PMPE}}=516,{ }^{2} \mathrm{~J}_{\mathrm{PMPD}}=14,{ }^{2} \mathrm{~J} \mathrm{PMPX}=16\right), 53.9\left(\mathrm{~m}, \mathrm{P}_{\mathrm{X}},{ }^{1} \mathrm{~J}_{\mathrm{PXPA}}=\right.$ $\left.390,{ }^{1} \mathrm{~J}_{\mathrm{PXPD}}=370,{ }^{2} \mathrm{~J}_{\mathrm{PXPE}}=11,{ }^{2} \mathrm{~J}_{\mathrm{PXPM}}=16\right)$.

\subsection{Low Temperature NMR Experiments}

To a solution of $\left[\left\{\mathrm{Cp}^{\prime \prime \prime} \mathrm{Fe}(\mathrm{CO})_{2}\right\}_{2}\left(\mu, \eta^{1: 1}-\mathrm{P}_{4}\right)\right](\mathbf{1})(100 \mathrm{mg}, 0.122 \mathrm{mmol})$ and TlOTf $(65 \mathrm{mg}$, $0.183 \mathrm{mmol}$ ) in $5 \mathrm{~mL}$ dichloromethane, a standard solution of a chlorophosphine $\mathrm{R}_{2} \mathrm{PCl}$ $(\mathrm{R}=\mathrm{Ph}, \mathrm{Me}, 0.122 \mathrm{M})$ in toluene was added at $193 \mathrm{~K}$. While stirring for $5 \mathrm{~h}$, a colourless precipitate of $\mathrm{TlCl}$ was formed from which the dark red solution was quickly but meticulously decanted at $193 \mathrm{~K}$ into a cooled Schlenk flask after sedimentation. The solvent was carefully removed at $193 \mathrm{~K}$, the dark red oil redissolved in precooled $\mathrm{CD}_{2} \mathrm{Cl}_{2}$ and was transferred into a precooled NMR tube with a J. Young valve, maintaining $193 \mathrm{~K}$ at all times. For mass spectrometry, the time between removing the sample (before removing the solvent) from the cooled Schlenk and the injection was minimized to ca. $2 \min .{ }^{31} \mathrm{P}\left\{{ }^{1} \mathrm{H}\right\}$ NMR spectro- 
scopic data show full conversion of $1 .{ }^{1} \mathrm{H}$ NMR of reac. mix. for $\mathrm{R}=\mathrm{Ph}-\left(\mathrm{CD}_{2} \mathrm{Cl}_{2}, 300 \mathrm{~K}\right)$ :

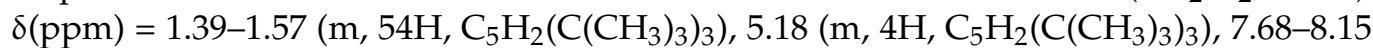
$\left(\mathrm{m}, 10 \mathrm{H}, \mathrm{P}\left(\mathrm{C}_{6} \mathrm{H}_{5}\right)_{2}\right)$; ESI-MS- $m / z=1001\left([\mathrm{M}]^{+}\right), 971\left([\mathrm{M}]^{+}-\mathrm{CO}\right), 943\left([\mathrm{M}]^{+}-2 \mathrm{CO}\right) ;{ }^{31} \mathrm{P}\left\{{ }^{1} \mathrm{H}\right\}$ NMR of $2 \mathbf{a}\left(\mathrm{CD}_{2} \mathrm{Cl}_{2}, 193 \mathrm{~K}\right)-\delta(\mathrm{ppm})=54.5\left(\mathrm{~m}, \mathrm{P}_{\mathrm{A}},{ }^{1} \mathrm{~J} \mathrm{PAPD}=379,{ }^{1} \mathrm{~J}_{\mathrm{PAPM}}=256,{ }^{1} \mathrm{~J}_{\mathrm{PAPX}}=\right.$ $\left.134,{ }^{2} \mathrm{~J}_{\mathrm{PAPQ}}=19\right), 3.9\left(\mathrm{~m}, \mathrm{P}_{\mathrm{D}},{ }^{1} \mathrm{~J}_{\mathrm{PDPA}}=379,{ }^{1} \mathrm{~J}_{\mathrm{PDPQ}}=254,{ }^{2} \mathrm{~J}_{\mathrm{PDPM}}=29,{ }^{2} \mathrm{~J}_{\mathrm{PDPA}}=24\right),-80.7$ $\left(\mathrm{m}, \mathrm{P}_{\mathrm{M}},{ }^{1} \mathrm{JPMPA}_{\mathrm{PMP}}=256,{ }^{1} \mathrm{~J}_{\mathrm{PMPQ}}=211,{ }^{1} \mathrm{~J}_{\mathrm{PMPX}}=228,{ }^{2} \mathrm{~J}_{\mathrm{PMPD}}=29\right),-135.0\left(\mathrm{~m}, \mathrm{P}_{\mathrm{Q}},{ }^{1} \mathrm{~J}_{\mathrm{PQPD}}=\right.$ $\left.254,{ }^{1} \mathrm{~J}_{\mathrm{PQPM}}=211,{ }^{1} \mathrm{~J}_{\mathrm{PQPX}}=122,{ }^{2} \mathrm{~J}_{\mathrm{PQPA}}=19\right),-192.8\left(\mathrm{~m}, \mathrm{P}_{\mathrm{X}},{ }^{1} \mathrm{~J}_{\mathrm{PXPA}}=134,{ }^{1} \mathrm{~J}_{\mathrm{PXPM}}=228\right.$, $\left.{ }^{1} \mathrm{~J}_{\mathrm{PXPQ}}=122,{ }^{2} \mathrm{~J}_{\mathrm{PXPD}}=24\right) ;{ }^{31} \mathrm{P}\left\{{ }^{1} \mathrm{H}\right\} \mathrm{NMR}$ of $3 \mathbf{a}\left(\mathrm{CD}_{2} \mathrm{Cl}_{2}, 193 \mathrm{~K}\right)-\delta(\mathrm{ppm})=78.4\left(\mathrm{~m}, \mathrm{P}_{\mathrm{A}}\right.$, $\left.{ }^{1} \mathrm{~J}_{\mathrm{PAPD}}=390,{ }^{1} \mathrm{~J}_{\mathrm{PAPX}}=218\right), 35.0\left(\mathrm{~m}, \mathrm{P}_{\mathrm{D}},{ }^{1} \mathrm{~J}_{\mathrm{PDPA}}=390,{ }^{1} \mathrm{~J}_{\mathrm{PDPV}}=283,{ }^{2} \mathrm{~J}_{\mathrm{PDPM}}=76,{ }^{1} \mathrm{~J}_{\mathrm{PDPX}}=\right.$ $68),-31.7\left(\mathrm{~m}, \mathrm{P}_{\mathrm{M}},{ }^{1} \mathrm{~J}_{\mathrm{PMPV}}=190,{ }^{1} \mathrm{~J}_{\mathrm{PMPX}}=260,{ }^{2} \mathrm{~J}_{\mathrm{PMPD}}=76\right),-134.5\left(\mathrm{~m}, \mathrm{P}_{\mathrm{V}},{ }^{1} \mathrm{~J}_{\mathrm{PVPD}}=283\right.$, $\left.{ }^{1} \mathrm{~J}_{\mathrm{PVPM}}=190,{ }^{1} \mathrm{JPVPX}_{\mathrm{PV}}=119\right),-148.7\left(\mathrm{~m}, \mathrm{P}_{\mathrm{X}},{ }^{1} \mathrm{~J}_{\mathrm{PXPA}}=218,{ }^{1} \mathrm{~J} \mathrm{PXPM}=260,{ }^{1} \mathrm{~J} \mathrm{PXPV}=119,{ }^{2} \mathrm{~J}\right.$ PXPD $=68) ;{ }^{1} \mathrm{H}$ NMR of reac. mix. for $\mathrm{R}=\mathrm{Me}-\left(\mathrm{CD}_{2} \mathrm{Cl}_{2}, 193 \mathrm{~K}\right): \delta(\mathrm{ppm})=1.42-1.57(\mathrm{~m}, 54 \mathrm{H}$,

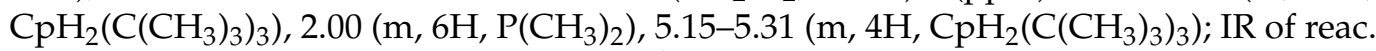
mix. for $\mathrm{R}=\mathrm{Me}-\left(\mathrm{CH}_{2} \mathrm{Cl}_{2}, 300 \mathrm{~K}\right): v\left(\mathrm{~cm}^{-1}\right)=1966$ (s), 2015 (s), 2046 (s); ESI-MS- $m / z=$ $875\left(\left[\left\{\mathrm{Cp}^{\prime \prime \prime} \mathrm{Fe}(\mathrm{CO})_{2}\right\}_{2}(\mu, \eta 1: 1-\mathrm{P} 4)\right]+\left[\mathrm{Me}_{2} \mathrm{P}\right]^{+}\right), 847\left([\mathrm{M}]^{+}-\mathrm{CO}\right), 819\left([\mathrm{M}]^{+}-2 \mathrm{CO}\right) ;{ }^{31} \mathrm{P}\left\{{ }^{1} \mathrm{H}\right\} \mathrm{NMR}$ of $2 \mathbf{b}\left(\mathrm{CD}_{2} \mathrm{Cl}_{2}, 193 \mathrm{~K}\right)-\delta(\mathrm{ppm})=45.6\left(\mathrm{~m}, \mathrm{P}_{\mathrm{A}},{ }^{1} \mathrm{~J}_{\mathrm{PAPB}}=352,{ }^{1} \mathrm{~J}_{\mathrm{PAPW}}=223,{ }^{1} \mathrm{~J}_{\mathrm{PAPB}}=352\right)$, $37.4\left(\mathrm{~m}, \mathrm{P}_{\mathrm{B}},{ }^{1} \mathrm{~J}_{\mathrm{PBPA}}=352,{ }^{1} \mathrm{JPBPM}=265,{ }^{1} \mathrm{~J}_{\mathrm{PBPX}}=106,{ }^{2} \mathrm{~J}_{\mathrm{PBPW}}=60\right),-48.6\left(\mathrm{~m}, \mathrm{P}_{\mathrm{M}},{ }^{1} \mathrm{~J}_{\mathrm{PMPB}}=\right.$ $\left.265,{ }^{1} \mathrm{JPMP}_{\mathrm{PMP}}=192,{ }^{2} \mathrm{~J}_{\mathrm{PMPW}}=99\right),-146.0\left(\mathrm{~m}, \mathrm{P}_{\mathrm{W}},{ }^{1} \mathrm{~J}_{\mathrm{PWPA}}=223,{ }^{1} \mathrm{~J}_{\mathrm{PWPX}}=261,{ }^{2} \mathrm{~J}_{\mathrm{PWPB}}=60\right.$, $\left.{ }^{2} \mathrm{~J}_{\mathrm{PWPM}}=99\right),-150.7\left(\mathrm{~m}, \mathrm{P}_{\mathrm{X}}, \mathrm{J}_{\mathrm{PXPB}}=106,{ }^{1} \mathrm{~J}_{\mathrm{PXPM}}=192, \mathrm{~J}_{\mathrm{PXPW}}=261\right) ;{ }^{31} \mathrm{P}\left\{{ }^{1} \mathrm{H}\right\}$ NMR of $3 \mathbf{b}$ $\left(\mathrm{CD}_{2} \mathrm{Cl}_{2}, 193 \mathrm{~K}\right)-\delta(\mathrm{ppm})=39.6\left(\mathrm{~m}, \mathrm{P}_{\mathrm{A}},{ }^{1} \mathrm{~J}_{\mathrm{PAPD}}=353,{ }^{1} \mathrm{~J}_{\mathrm{PAPM}}=243,{ }^{1} \mathrm{JPAPX}=130,{ }^{2} \mathrm{~J}_{\mathrm{PAPQ}}=\right.$ 25), $2.1\left(\mathrm{~m}, \mathrm{P}_{\mathrm{D}},{ }^{1} \mathrm{~J}_{\mathrm{PDPA}}=353,{ }^{1} \mathrm{~J}_{\mathrm{PDPQ}}=244,{ }^{2} \mathrm{~J}_{\mathrm{PDPM}}=32,{ }^{1} \mathrm{~J}_{\mathrm{PDPX}}=26\right),-82.6\left(\mathrm{~m}, \mathrm{P}_{\mathrm{M}},{ }^{1} \mathrm{~J}_{\mathrm{PMPA}}\right.$ $\left.=243,{ }^{1} \mathrm{~J}_{\mathrm{PMPQ}}=206,{ }^{1} \mathrm{JPMPX}=237,{ }^{2} \mathrm{JPMPD}=32\right),-140.2\left(\mathrm{~m}, \mathrm{P}_{\mathrm{Q}},{ }^{1} \mathrm{~J}_{\mathrm{PQPD}}=244,{ }^{1} \mathrm{JPQPM}=\right.$ $\left.206,{ }^{1} \mathrm{~J}_{\mathrm{PQPX}}=114,{ }^{2} \mathrm{~J}_{\mathrm{PQPA}}=25\right),-182.3\left(\mathrm{~m}, \mathrm{P}_{\mathrm{X}},{ }^{1} \mathrm{~J}_{\mathrm{PXPA}}=130,{ }^{1} \mathrm{~J}_{\mathrm{PXPM}}=237,{ }^{1} \mathrm{~J}_{\mathrm{PXP}}=114\right.$, $\left.{ }^{2} \mathrm{~J}_{\mathrm{PXPD}}=26\right)$.

\subsection{Reaction of $\mathbf{1}$ with in Situ Generated [Ph 2 As][OTf] at $193 \mathrm{~K}$}

To a mixture of $\left[\left\{\mathrm{Cp}^{\prime \prime \prime} \mathrm{Fe}(\mathrm{CO})_{2}\right\}_{2}\left(\mu, \eta^{1: 1}-\mathrm{P}_{4}\right)\right](1)(100 \mathrm{mg}$, $0.122 \mathrm{mmol})$, TlOTf (65 mg, $0.183 \mathrm{mmol}$ ) and $\mathrm{Ph}_{2} \mathrm{AsCl}(32 \mathrm{mg}, 0.122 \mathrm{mmol}), 10 \mathrm{~mL}$ of precooled dichloromethane was added at $193 \mathrm{~K}$ under stirring. After one hour of stirring and storing the mixture for two days at $193 \mathrm{~K}$ to let the colourless solid settle, the vibrant red solution is decanted via short Teflon tubing into a precooled Schlenk flask. After removing the solvent at $193 \mathrm{~K}$, a viscous, dark red oil is formed. ${ }^{31} \mathrm{P}\left\{{ }^{1} \mathrm{H}\right\}$ NMR spectra of the reaction solution showed full conversion of $\mathbf{1}$. Redissolving in o-DFB and adding the same volume of pentane to the dark red solution yielded $54 \mathrm{mg}(0.027 \mathrm{mmol}$, yield $44 \%$ of theory $)$ dark red crystals of 5 after storage at room temperature for $24 \mathrm{~h} .{ }^{1} \mathrm{H}$ NMR of reac. Mix- $\left(\mathrm{CD}_{2} \mathrm{Cl}_{2}, 193\right.$

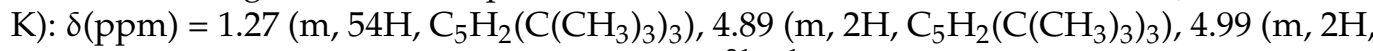
$\left.\mathrm{C}_{5} \mathrm{H}_{2}\left(\mathrm{C}\left(\mathrm{CH}_{3}\right)_{3}\right)_{3}\right), 7.54\left(\mathrm{~m}, 10 \mathrm{H}, \mathrm{As}\left(\mathrm{C}_{6} \mathrm{H}_{5}\right)_{2}\right) ;{ }^{31} \mathrm{P}\left\{{ }^{1} \mathrm{H}\right\}$ NMR of coordination mode 1 of $\left[\mathrm{Ph}_{2} \mathrm{As}\right][\mathrm{OTf}]$ on $1-\left(\mathrm{CD}_{2} \mathrm{Cl}_{2}, 193 \mathrm{~K}\right): \delta(\mathrm{ppm})=57.7\left(\mathrm{~m}, \mathrm{P}_{\mathrm{A}},{ }^{1} \mathrm{~J}_{\mathrm{PAPW}}=259,{ }^{1} \mathrm{~J}_{\mathrm{PAPX}}=244\right.$, $\left.{ }^{2} \mathrm{~J}_{\mathrm{PAPB}}=24\right), 43.8\left(\mathrm{~m}, \mathrm{P}_{\mathrm{B}},{ }^{1} \mathrm{~J}_{\mathrm{PBPW}}=214,{ }^{1} \mathrm{~J}_{\mathrm{PBPX}}=218,{ }^{2} \mathrm{~J}_{\mathrm{PBPA}}=24\right),-237.0\left(\mathrm{~m}, \mathrm{P}_{\mathrm{W}},{ }^{1} \mathrm{JPWPA}_{\mathrm{PWP}}=\right.$ $\left.259,{ }^{1} \mathrm{~J}_{\mathrm{PWPB}}=214,{ }^{1} \mathrm{~J}_{\mathrm{PWPX}}=109\right),-250.6\left(\mathrm{~m}, \mathrm{P}_{\mathrm{X}},{ }^{1} \mathrm{~J}_{\mathrm{PXPA}}=244,{ }^{1} \mathrm{~J}_{\mathrm{PXPB}}=218,{ }^{1} \mathrm{~J}_{\mathrm{PXPW}}=109\right)$; ${ }^{31} \mathrm{P}\left\{{ }^{1} \mathrm{H}\right\}$ NMR of coordination mode 2 of $\left[\mathrm{Ph}_{2} \mathrm{As}\right][\mathrm{OTf}]$ on $\mathbf{1}\left(\mathrm{CD}_{2} \mathrm{Cl}_{2}, 193 \mathrm{~K}\right)-\delta(\mathrm{ppm})=$ $-10.9\left(\mathrm{~m}, \mathrm{P}_{\mathrm{A}},{ }^{1} \mathrm{~J}_{\mathrm{PAPB}}=125,{ }^{1} \mathrm{~J}_{\mathrm{PAPX}}=203\right),-12.1\left(\mathrm{~m}, \mathrm{P}_{\mathrm{B}},{ }^{1} \mathrm{~J}_{\mathrm{PBPA}}=125,{ }^{1} \mathrm{JPBPX}_{\mathrm{PBP}}=256\right),-274.9$ $\left(\mathrm{m}, 2 \mathrm{P}_{\mathrm{X}},{ }^{1} \mathrm{~J}_{\mathrm{PXPA}}=203,{ }^{1} \mathrm{~J}_{\mathrm{PXPB}}=256\right)$; Analytical data for isolated crystals of 5: EA-Expected for $\left(\mathrm{C}_{78} \mathrm{H}_{116} \mathrm{~F}_{6} \mathrm{Fe}_{4} \mathrm{O}_{14} \mathrm{P}_{8} \mathrm{~S}_{2}(5)+0.6 \mathrm{C}_{6} \mathrm{H}_{4} \mathrm{~F}_{2}\right): 49.11 \mathrm{C}, 5.98 \% \mathrm{H}, 3.21 \% \mathrm{~S}$. Found: $49.64 \%$ C, 5.70\% H, 3.72\% S; IR: $v\left(\mathrm{~cm}^{-1}\right)=1964$ (s), 1989 (s), 2029 (s), 2032 (s); ESI-MS- $m / z=$

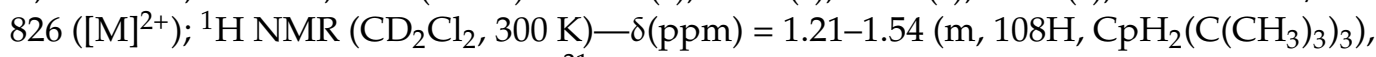

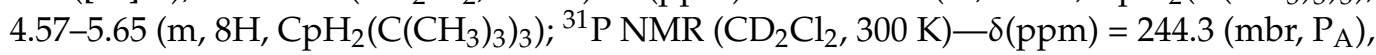
$183.3\left(\mathrm{mbr}, \mathrm{P}_{\mathrm{E}}\right), 136.3\left(\mathrm{~m}, \mathrm{P}_{\mathrm{G}}\right), 128.4\left(\mathrm{mbr}, \mathrm{P}_{\mathrm{H}}\right), 69.5\left(\mathrm{mbr}, \mathrm{P}_{\mathrm{M}}\right), 40.3\left(\mathrm{mbr}, \mathrm{P}_{\mathrm{Q}}\right), 2.5\left(\mathrm{mbr}, \mathrm{P}_{\mathrm{T}}\right)$, $-165.4\left(\mathrm{~m}, \mathrm{PX}_{\mathrm{X}}\right)$.

\section{Conclusions}

It could be shown that the insertion of phosphenium ions into the bicylo-[1.1.0]tetraphosphabutane unit of $\left[\left\{\mathrm{Cp}^{\prime \prime \prime} \mathrm{Fe}(\mathrm{CO})_{2}\right\}_{2}\left(\mu, \eta^{1: 1}-\mathrm{P}_{4}\right)\right](\mathbf{1})$ is possible. Due to the sensitivity of the reaction solutions, extensive low-temperature NMR studies involving ${ }^{31} \mathrm{P}_{-}{ }^{31} \mathrm{P}$ COSY 
NMR and iterative simulation of the complex spin systems were performed to ascertain the connectivity of the phosphorus cores of the compounds formed at $193 \mathrm{~K}$. These resulted in the characterization of a 2-diphenylphosphabicyclo[1.1.0]tetraphosphabutane unit in 2a as well as a rarely observed bicyclo[2.1.0]pentaphosphapentane unit in $\left[\left\{\mathrm{Cp}^{\prime \prime \prime} \mathrm{Fe}(\mathrm{CO})_{2}\right\}_{2}\left(\mu, \eta^{1: 1}\right.\right.$ $\left.\left.\mathrm{P}_{5}\left(\mathrm{C}_{6} \mathrm{H}_{5}\right)_{2}\right)\right]\left[\mathrm{PF}_{6}\right](3 \mathrm{a})$, which could be confirmed by single crystal X-ray diffraction. Regardless of the low isolated yield of crystalline $3 a$ and 4 , the ${ }^{31}$ P NMR spectra of freshly prepared reaction solutions show full conversion of $\mathbf{1}$ to the corresponding products. Additionally, DFT computations were used to gain more insight into the decarbonylation process of $3 \mathbf{a}$ to the cationic compound $\left[\left\{\mathrm{Cp}^{\prime \prime \prime} \mathrm{Fe}\right\}\left(\mu, \eta^{4: 1}-\mathrm{P}_{5}\left(\mathrm{C}_{6} \mathrm{H}_{5}\right)_{2}\right)\left\{\mathrm{Cp}^{\prime \prime \prime}(\mathrm{CO})_{2} \mathrm{Fe}\right\}\right]\left[\mathrm{PF}_{6}\right](4)$. Furthermore, the reactivity of diphenylarsenium ions towards $\mathbf{1}$ was investigated, showing two temperature-sensitive coordination products by applying low-temperature NMR studies. By exposing solutions of these product mixtures to room temperature, the formation of $\mathrm{Ph}_{4} \mathrm{As}_{2}$ and the disproportionation product $\left[\left\{\mathrm{Cp}^{\prime \prime \prime} \mathrm{Fe}(\mathrm{CO})_{2}\right\}_{4}\left(\mu_{4} \eta^{1: 1: 1: 1}-\mathrm{P}_{8}\right)\right][\mathrm{OTf}]_{2}(5)$ with a rarely found tetracyclo[3.3.0.0 $\left.0^{2,7} \cdot 0^{3,6}\right]$ octaphosphaoctane unit could be observed.

Supplementary Materials: The following are available online. NMR spectra with the assignment of phosphorus atoms, details of the crystal structure refinements and the DFT calculations.

Author Contributions: Conceptualization: M.W., G.B. and M.S.; methodology, M.W.; software, M.W. and G.B.; validation, M.W. and G.B.; formal analysis, M.W., A.V.V. and E.P.; investigation, M.W.; resources, M.S.; data curation, M.W.; writing—original draft preparation, M.W.; writing-review and editing, M.W., G.B., A.V.V., E.P. and M.S.; visualization, M.W.; supervision, M.S. and G.B.; project administration, M.S.; funding acquisition, M.S. All authors have read and agreed to the published version of the manuscript.

Funding: This work was supported by the Deutsche Forschungsgemeinschaft within the project Sche 384/36-1.

Institutional Review Board Statement: Not applicable.

Informed Consent Statement: Not applicable.

Data Availability Statement: The data presented in this study are available in supplementary material.

Acknowledgments: M.W. thanks Julian Müller for his expertise and Georgine Stühler from the NMR Department of the University of Regensburg for her patience with all the VT-NMR measurements taking the special requirements of the samples into account. Parts of this research were carried out at PETRA III at DESY, a member of the Helmholtz Association (HGF). The authors would like to thank S. Saouane and J. Hakanpää for their assistance regarding the use of the beamline P11 (Project I-20190914).

Conflicts of Interest: The authors declare no conflict of interest.

Sample Availability: Not applicable.

\section{References}

1. Cossairt, B.M.; Piro, N.A.; Cummins, C.C. Early-transition-metal-mediated activation and transformation of white phosphorus. Chem. Rev. 2010, 110, 4164-4177. [CrossRef]

2. Scheer, M.; Balázs, G.; Seitz, A. $\mathrm{P}_{4}$ activation by main group elements and compounds. Chem. Rev. 2010, 110, 4236-4256. [CrossRef]

3. Caporali, M.; Gonsalvi, L.; Rossin, A.; Peruzzini, M. $\mathrm{P}_{4}$ activation by late-transition metal complexes. Chem. Rev. 2010, 110, 4178-4235. [CrossRef]

4. Khan, S.; Sen, S.S.; Roesky, H.W. Activation of phosphorus by group 14 elements in low oxidation states. Chem. Commun. 2012, 48 , 2169-2179. [CrossRef] [PubMed]

5. $\quad$ Borger, J.E.; Jongkind, M.K.; Ehlers, A.W.; Lutz, M.; Slootweg, J.C.; Lammertsma, K. Metalate-Mediated Functionalization of P 4 by Trapping Anionic $\mathrm{Cp}{ }^{*} \mathrm{Fe}(\mathrm{CO})_{2}\left(\eta^{1}-\mathrm{P}_{4}\right)^{-}$with Lewis Acids. ChemistryOpen 2017, 6, 350-353. [CrossRef]

6. Ginsberg, A.P.; Lindsell, W.E. Rhodium complexes with the molecular unit $\mathrm{P}_{4}$ as a ligand. J. Am. Chem. Soc. 1971, 93, 2082-2084. [CrossRef]

7. Scherer, O.J.; Hilt, T.; Wolmershäuser, G. $\mathrm{P}_{4}$ Activation with $\left[\left\{\mathrm{Cp}^{\prime \prime \prime}(\mathrm{OC})_{2} \mathrm{Fe}_{2}\right]\left(\mathrm{Cp}^{\prime \prime \prime}=\mathrm{C}_{5} \mathrm{H}_{2} \mathrm{tBu} \mathrm{Bu}_{3}-1,2,4\right)\right.$ : Exclusive Formation of the Exo/ Exo-Butterfly Complex $\left[\left\{\mathrm{Cp}^{\prime \prime \prime}(\mathrm{OC})_{2} \mathrm{Fe}\right\}_{2}\left(\mu-\eta^{1}: \eta^{1}-\mathrm{P}_{4}\right)\right]$. Organometallics 1998, 17, 4110-4112. [CrossRef] 
8. Schwarzmaier, C.; Timoshkin, A.Y.; Balázs, G.; Scheer, M. Selective Formation and Unusual Reactivity of Tetraarsabicyclo[1.1.0]butane Complexes. Angew. Chem. Int. Ed. 2014, 53, 9077-9081. [CrossRef]

9. Müller, J.; Balázs, G.; Scheer, M. From a $\mathrm{P}_{4}$ butterfly scaffold to cyclo- and catena-P 4 units. Chem. Commun. 2021, 57, 2257-2260. [CrossRef]

10. Müller, J.; Heinl, S.; Schwarzmaier, C.; Balázs, G.; Keilwerth, M.; Meyer, K.; Scheer, M. Rearrangement of a $\mathrm{P}_{4}$ Butterfly ComplexThe Formation of a Homoleptic Phosphorus-Iron Sandwich Complex. Angew. Chem. Int. Ed. Engl. 2017, 56, 7312-7317. [CrossRef] [PubMed]

11. Grünbauer, R.; Schwarzmaier, C.; Eberl, M.; Balázs, G.; Scheer, M. The reactivity of the $\mathrm{P}_{4}$-butterfly ligand $\left[\left\{\mathrm{Cp} \mathrm{p}^{\prime \prime \prime} \mathrm{Fe}(\mathrm{CO})_{2}\right\}_{2}\left(\mu, \eta^{1: 1}\right.\right.$ $\left.\mathrm{P}_{4}\right)$ ] towards transition metal complexes: Coordination versus rearrangement. Inorg. Chim. Acta 2021, 518, 120234. [CrossRef]

12. Schwarzmaier, C.; Heinl, S.; Balázs, G.; Scheer, M. $\mathrm{E}_{4}$ Butterfly Complexes (E = P, As) as Chelating Ligands. Angew. Chem. Int. Ed. Engl. 2015, 54, 13116-13121. [CrossRef]

13. Reichl, S.; Grünbauer, R.; Balázs, G.; Scheer, M. Reactivity of $\mathrm{P}_{4}$ butterfly complexes towards NHCs - generation of a metal-bridged $\mathrm{P}_{2}$ dumbbell complex. Chem. Commun. 2021, 57, 3383-3386. [CrossRef] [PubMed]

14. Grünbauer, R.; Balázs, G.; Scheer, M. The Butterfly Complex $\left\{\mathrm{Cp} \mathrm{p}^{*} \mathrm{Cr}(\mathrm{CO})_{3}\right\}_{2}\left(\mu, \eta^{1: 1}-\mathrm{P}_{4}\right)$ as a Versatile Ligand and Its Unexpected $\mathrm{P}_{1} / \mathrm{P}_{3}$ Fragmentation. Chemistry 2020, 26, 11722-11726. [CrossRef] [PubMed]

15. Giffin, N.A.; Masuda, J.D. Reactivity of white phosphorus with compounds of the p-block. Coord. Chem. Rev. 2011, 255, 1342-1359. [CrossRef]

16. Weigand, J.J.; Holthausen, M.; Fröhlich, R. Formation of $\left[\mathrm{Ph}_{2} \mathrm{P}_{5}\right]^{+},\left[\mathrm{Ph}_{4} \mathrm{P}_{6}\right]^{2+}$, and $\left[\mathrm{Ph}_{6} \mathrm{P}_{7}\right]^{3+}$ Cationic Clusters by Consecutive Insertions of $\left[\mathrm{Ph}_{2} \mathrm{P}\right]^{+}$into P-P Bonds of the $\mathrm{P}_{4}$ Tetrahedron. Angew. Chem. Int. Ed. Engl. 2009, 48, 295-298. [CrossRef]

17. Burford, N.; Cameron, T.S.; Ragogna, P.J.; Ocando-Mavarez, E.; Gee, M.; McDonald, R.; Wasylishen, R.E. Phosphine ligand exchange at a phosphine lewis acceptor: The first structural characterization of homoleptic phosphinophosphonium salts. J. Am. Chem. Soc. 2001, 123, 7947-7948. [CrossRef]

18. Burford, N.; Cameron, T.S.; LeBlanc, D.J.; Losier, P.; Sereda, S.; Wu, G. Structural Alternatives in $\mathrm{R}_{2}(\mathrm{Cl}) \mathrm{P}: \mathrm{GaCl}_{3} \mathrm{Systems}(\mathrm{R}=$ Alkyl, Phenyl), Including Examples of Intermolecular P $\rightarrow$ P Coordination. Organometallics 1997, 16, 4712-4717. [CrossRef]

19. Dyker, C.A.; Burford, N. Catena-phosphorus cations. Chem. Asian J. 2008, 3, 28-36. [CrossRef]

20. Weigand, J.J.; Burford, N.; Lumsden, M.D.; Decken, A. A Melt Approach to the Synthesis ofcatena-Phosphorus Dications To Access Derivatives of $\left[\mathrm{P}_{6} \mathrm{Ph}_{4} \mathrm{R}_{4}\right]^{2+}$. Angew. Chem. 2006, 118, 6885-6889. [CrossRef]

21. Chitnis, S.S.; MacDonald, E.; Burford, N.; Werner-Zwanziger, U.; McDonald, R. P-P Menschutkin preparation of prototypical phosphinophosphonium salts. Chem. Commun. 2012, 48, 7359-7361. [CrossRef] [PubMed]

22. Holthausen, M.H.; Weigand, J.J. The chemistry of cationic polyphosphorus cage-Syntheses, structure and reactivity. Chem. Soc. Rev. 2014, 43, 6639-6657. [CrossRef]

23. Burford, N.; Ragogna, P.J.; McDonald, R.; Ferguson, M.J. Phosphine coordination complexes of the diphenylphosphenium cation: A versatile synthetic methodology for P-P bond formation. J. Am. Chem. Soc. 2003, 125, 14404-14410. [CrossRef]

24. Weigand, J.J.; Burford, N.; Davidson, R.J.; Cameron, T.S.; Seelheim, P. New synthetic procedures to catena-phosphorus cations: Preparation and dissociation of the first cyclo-phosphino-halophosphonium salts. J. Am. Chem. Soc. 2009, 131, 17943-17953. [CrossRef]

25. Krossing, I.; Raabe, I. $\mathrm{P}_{5} \mathrm{X}_{2}{ }^{+}(\mathrm{X}=\mathrm{Br}, \mathrm{I})$, a Phosphorus-Rich Binary P-X Cation with a $\mathrm{C}(2 \mathrm{v})$-Symmetric $\mathrm{P}_{5}$ Cage. Angew. Chem. Int Ed. Engl. 2001, 40, 4406-4409. [CrossRef]

26. Riesinger, C.; Dütsch, L.; Balázs, G.; Bodensteiner, M.; Scheer, M. Cationic Functionalisation by Phosphenium Ion Insertion. Chem. Eur. J. 2020, 26, 17165-17170. [CrossRef]

27. Riesinger, C.; Balázs, G.; Bodensteiner, M.; Scheer, M. Stabilization of Pentaphospholes as $\eta^{5}$-Coordinating Ligands. Angew. Chem. Int. Ed. Engl. 2020, 59, 23879-23884. [CrossRef]

28. Kilah, N.L.; Petrie, S.; Stranger, R.; Wielandt, J.W.; Willis, A.C.; Wild, S.B. Triphenylphosphine-Stabilized Diphenyl-Arsenium, -Stibenium, and -Bismuthenium Salts. Organometallics 2007, 26, 6106-6113. [CrossRef]

29. Braddock, J.M.F.; Coates, G.E. 628. Arsinophosphonium salts. J. Chem. Soc. 1961, 3208-3211. [CrossRef]

30. Porter, K.A.; Willis, A.C.; Zank, J.; Wild, S.B. Phosphine-stabilized arsenium salts: Water-stable, labile, coordination complexes. Inorg. Chem. 2002, 41, 6380-6386. [CrossRef]

31. Bernstein, H.J.; Pople, J.A.; Schneider, W.G. The Analysis of Nuclear Magnetic Resonance Spectra: I. Systems of two and three Nuclei. Can. J. Chem. 1957, 35, 65-81. [CrossRef]

32. Adhikari, A.K.; Ziegler, C.G.P.; Schwedtmann, K.; Taube, C.; Weigand, J.J.; Wolf, R. Functionalization of Pentaphosphorus Cations by Complexation. Angew. Chem. Int. Ed. Engl. 2019, 58, 18584-18590. [CrossRef]

33. Hennersdorf, F.; Weigand, J.J. A Tetracyclic Octaphosphane by Successive Addition, Inversion, and Condensation Reactions. Angew. Chem. Int. Ed. Engl. 2017, 56, 7858-7862. [CrossRef] [PubMed]

34. Barr, M.E.; Adams, B.R.; Weller, R.R.; Dahl, L.F. Synthesis and structural-bonding analysis of $\left.\left[\eta^{5}-\mathrm{C}_{5} \mathrm{H}_{4} \mathrm{Me}\right)_{4} \mathrm{Fe}_{4}(\mathrm{CO})_{6} \mathrm{P}_{8}\right]$ and $\left.\left[\eta^{5}-\mathrm{C}_{5} \mathrm{H}_{4} \mathrm{Me}\right)_{4} \mathrm{Fe}_{6}(\mathrm{CO})_{13} \mathrm{P}_{8}\right]$ : Two unprecedented transition-metal complexes containing the cage-like $\mathrm{P}_{8}$ subunit of Hittorf's monoclinic phosphorus allotrope. J. Am. Chem. Soc. 1991, 113, 3052-3060. [CrossRef]

35. Deringer, V.L.; Pickard, C.J.; Proserpio, D.M. Hierarchically Structured Allotropes of Phosphorus from Data-Driven Exploration. Angew. Chem. Int. Ed. Engl. 2020, 59, 15880-15885. [CrossRef] 
36. Mädl, E.; Balázs, G.; Peresypkina, E.V.; Scheer, M. Unexpected Reactivity of $\left.\left(\eta^{5}-1,2,4-\mathrm{tBuC}_{5} \mathrm{H}_{2}\right) \mathrm{Ni}_{(} \eta^{3}-\mathrm{P}_{3}\right)$ towards Main Group Nucleophiles and by Reduction. Angew. Chem. Int. Ed. Engl. 2016, 55, 7702-7707. [CrossRef]

37. Scheer, M.; Becker, U.; Matern, E. Ir-Komplexe mit $\mathrm{P}_{4}$-Bicyclotetraphosphan und $\mathrm{P}_{8}$-Cunean als Liganden-CO-Insertion in eine Ir-P-Bindung. Chem. Ber. 1996, 129, 721-724. [CrossRef]

38. Hennersdorf, F.; Frötschel, J.; Weigand, J.J. Selective Derivatization of a Hexaphosphane from Functionalization of White Phosphorus. J. Am. Chem. Soc. 2017, 139, 14592-14604. [CrossRef] [PubMed]

39. Spitzer, F.; Graßl, C.; Balázs, G.; Zolnhofer, E.M.; Meyer, K.; Scheer, M. Influence of the nacnac Ligand in Iron(I)-Mediated P 4 Transformations. Angew. Chem. Int. Ed. Engl. 2016, 55, 4340-4344. [CrossRef] [PubMed]

40. Huang, W.; Diaconescu, P.L. $\mathrm{P}_{4}$ activation by group 3 metal arene complexes. Chem. Commun. 2012, 48, 2216-2218. [CrossRef] [PubMed]

41. Konchenko, S.N.; Pushkarevsky, N.A.; Gamer, M.T.; Köppe, R.; Schnöckel, H.; Roesky, P.W. $\left\{\left(\eta^{5}-\mathrm{C}_{5} \mathrm{Me}_{5}\right)_{2} \mathrm{Sm}_{4} \mathrm{P}_{8}\right.$ : A molecular polyphosphide of the rare-earth elements. J. Am. Chem. Soc. 2009, 131, 5740-5741. [CrossRef] [PubMed]

42. Lerner, H.-W.; Margraf, G.; Kaufmann, L.; Bats, J.W.; Bolte, M.; Wagner, M. Syntheses, Reactivity, and X-ray Structure Analyses of the Dimeric Pentaphosphides $\left[\left(\mathrm{tBu}_{3} \mathrm{Si}_{3} \mathrm{P}_{5} \mathrm{M}_{2}\right]_{2}(\mathrm{M}=\mathrm{Na}, \mathrm{Ag})\right.$ and the Bicyclo[2.1.0]pentaphosphane $\left(\mathrm{tBu}_{3} \mathrm{Si}\right)_{3} \mathrm{P}_{5}$. Eur. J. Inorg. Chem. 2005, 2005, 1932-1939. [CrossRef]

43. Butovskiy, M.V.; Balázs, G.; Bodensteiner, M.; Peresypkina, E.V.; Virovets, A.V.; Sutter, J.; Scheer, M. Ferrocene and pentaphosphaferrocene: A comparative study regarding redox chemistry. Angew. Chem. Int. Ed. Engl. 2013, 52, 2972-2976. [CrossRef]

44. Mädl, E.; Butovskii, M.V.; Balázs, G.; Peresypkina, E.V.; Virovets, A.V.; Seidl, M.; Scheer, M. Functionalization of a cyclo-P 5 ligand by main-group element nucleophiles. Angew. Chem. Int. Ed. Engl. 2014, 53, 7643-7646. [CrossRef]

45. Krossing, I. The Facile Preparation of Weakly Coordinating Anions: Structure and Characterisation of Silverpolyfluoroalkoxyaluminates $\mathrm{AgAl}\left(\mathrm{OR}_{\mathrm{F}}\right)_{4}$, Calculation of the Alkoxide Ion Affinity. Chem. Eur. J. 2001, 7, 490-502. [CrossRef]

46. Scherer, O.J.; Schwarz, G.; Wolmershäuser, G. Eisen-Zweikernkomplexe mit unterschiedlichen $\mathrm{P}_{4}$-Liganden. Z. Anorg. Allg. Chem. 1996, 622, 951-957. [CrossRef]

47. Cullen, W.R.; Trotter, J. Crystal data for diphenylarsenicals. Can. J. Chem. 1961, 39, 2602-2603. [CrossRef]

48. Burkhardt, A.; Pakendorf, T.; Reime, B.; Meyer, J.; Fischer, P.; Stübe, N.; Panneerselvam, S.; Lorbeer, O.; Stachnik, K.; Warmer, M.; et al. Status of the crystallography beamlines at PETRA III. Eur. Phys. J. Plus 2016, 131, 56. [CrossRef] 